UNIVERSIDADE DE SÃO PAULO

FACULDADE DE MEDICINA DE RIBEIRÃO PRETO

PÓS-GRADUAÇÃO EM IMUNOLOGIA BÁSICA E APLICADA

\title{
Papel de CCR5 na infecção oral por
}

\section{Toxoplasma gondii}

\section{GIULIANO BONFÁ}

Ribeirão Preto - SP 


\section{GIULIANO BONFÁ}

\section{Papel de CCR5 na infecção oral por}

\section{Toxoplasma gondii}

Dissertação apresentada ao curso de Pósgraduação em Imunologia Básica e Aplicada da Faculdade de Medicina de Ribeirão Preto Universidade de São Paulo, para a obtenção do grau de Mestre em Ciências - Área de concentração: Imunologia Básica e Aplicada.

Orientação: Prof. Dr. João Santana da Silva 
AUTORIZO A REPRODUÇÃO E DIVULGAÇÃO TOTAL OU PARCIAL DESTE TRABALHO, POR QUALQUER MEIO CONVENCIONAL OU ELETRÔNICO, PARA FINS DE ESTUDO E PEQUISA, DESDE QUE CITADA A FONTE.

Catalogação da publicação

Faculdade de Medicina de Ribeirão Preto

Universidade de São Paulo

Bonfá, Giuliano

Papel de CCR5 na infecção oral por $T$. gondii

Ribeirão Preto, 2010.

78 f.: Il.; $30 \mathrm{~cm}$

Dissertação de mestrado, apresentada à Faculdade de Medicina de Ribeirão Preto/FMRP-USP - Área de concentração: Imunologia Básica e Aplicada.

Orientador: João Santana da Silva

1. Infecção oral; 2. Toxoplasma gondii; 3. Receptor de quimiocina CCR5; 4. Lesão tecidual. 
Nome: BONFÁ, Giuliano

Título: Papel de CCR5 na infecção oral por T. gondii

Dissertação apresentada ao curso de Pós-graduação em Imunologia Básica e Aplicada da Faculdade de Medicina de Ribeirão Preto - Universidade de São Paulo, para a obtenção do grau de Mestre em Ciências - Área de concentração: Imunologia Básica e Aplicada.

Aprovado em:

Banca Examinadora

Prof. Dr. Instituição:

Julgamento: Assinatura:

Prof. Dr. Instituição:

Julgamento: Assinatura:

Prof. Dr. Instituição:

Julgamento: Assinatura: 
Trabalho realizado no Laboratório de Imunoparasitologia do Departamento de Bioquímica e Imunologia - Faculdade de Medicina de Ribeirão Preto - Universidade de São Paulo FMRP/USP, com auxílio financeiro da FAPESP, CAPES e CNPq (132129/2008-6). 
Dedico este trabalho à toda mínha familia, em especial aos meus pais, Emiliano e Mercilia, e às mínhas querídas írmãs Jana Nelma e Jamila, pelo amor íncondicional. Por terem me críado na humildade e no amor. Por me mostrarem o quanto a vída pode ser complexa e valiosa, fornecendo apoío nos momentos mais dificeís e compartilhando os momentos de alegría. Mesmo na distâncía, sempre vou sobreviver porque seí que posso contar com vocês, que me amam e me esperam. Amo muito vocês! 


\section{Agradecimentos}

À Deus pela presença constante e pelo temor que tanto me ajudou a recomeçar. À Jesus seu filho, pela graça e pela bondade, pela mansidão de coração, pelo exemplo a ser seguido. À nossa mãe Maria, por interçeder por mim e me mostrar tantas vezes por qual caminho seguir, por onde andar.

Ao Prof. Dr. João Santana da Silva por ter me orientado, transmitindo conhecimento e sabedoria durante o trabalho. Pelas constantes cobranças e pelos momentos de descontração vividos em seu laboratório.

Aos Professores Dra. Neide Maria da Silva e Dr. Tiago Wilson P. Mineo, pela coorientação durante o trabalho. Pela experiência dedicada, pela preoculpação durante o desenvolvimento do trabalho e pelas sugestões propostas.

Aos Professores Dr. Virmondes Rodrigues Junior (UFTM) e Dr. Ademilson Panunto Castelo (EERP-USP) pela disponibilidade em participar da banca examinadora, pelas sugestões e correções.

Ao Professor Dr. Paulo Marcos M. Guedes e aos Doutores Vanessa Carregaro e Fredy R. Salazar Gutierrez, que não mediram esforços para dedicação no laboratório e por todo auxílio e experiência prestados durante os experimentos, além da boa convivência e dos conselhos. Aos novos Doutores Renata Sesti Costa e Fabrício C. Dias, pela troca de experiências e pela amizade.

Ao grupo de pesquisa Toxoplasma gondii, em especial: Ms Luciana Benevides, pela paciência, experiência, ensinamentos, discussões e correções durante todo o desenvolvimento do trabalho. Serei eternamente grato a ela, principalmente pelos momentos de descontração e sofrimento vividos juntos, e por me mostrar que é possível ser ágil e eficiente. À Dra. Denise Morais da Fonseca que tanto me auxiliou nos momentos finais, nas correções e discussões sobre os experimentos. À Ms Maria do Carmo Souza pelo apoio nos experimentos, dedicação e amizade.

À todos os colegas do laboratório que direta ou indiretamente participaram do trabalho ou da vida, em especial: Moira, Fernanda, Maria Cláudia, Grace, Juliana, Fabrine, Diego, Djalma, Walter, Manuela, Tiago Medina, Gustavo, Carlo, Wanessa, Hellen, Sandra, Alessandra, Daniela, Karen e Gisele, pelos bons momentos que passamos juntos, pelos momentos de cantorias no fluxo laminar, pelos momentos de loucuras, piadas e resgate musical durante os exaustivos experimentos. Pela companhia e amizade. 
À Ana Cristine S. Ferreira, secretária da Pós-graduação, pela competência e dedicação com que realiza seu trabalho. Obrigado por tudo, pela acolhida materna, pelas brincadeiras e pela atenção.

À todos os funcionários, em especial: Cristiane Milanezi, pela amizade, simplicidade de personalidade e pelas trocas de experiência em PCR e Biologia Molecular. Ao Wander C. R. da Silva, Denise Ferraz, Júlio A. Siqueira, Edinelson Mazzoto, Calabrão, Cristina Ribas, Rinaldo B. Ferreira, Sávio Miranda, Rubens Campos, Lúcia Pacheco e Dona Vera, cuja contribuição e o trabalho prestado foram essenciais para o bom desenvolvimento deste trabalho.

À todos os Professores da Pós-graduação em Imunologia Básica e Aplicada que contribuíram com conhecimento em suas disciplinas e equipamentos em seus laboratórios.

À todos alunos e amigos da Pós-graduação em Imunologia Básica e Aplicada, Biologia Celular, Bioquímica e Farmacologia pelo convívio e amizade.

Aos meus amigos eternos do Grupo de Oração Universitário - GOU Sopro de Vida: Débora, Carol, Ana Paula, Ivã, Natália, Tiago, Karliane, Patrícia, Fernanda, Daniel, Regiane e Vera. A vida sem vocês no apoio aquí em Ribeirão certamente teria sido mais difícil. Obrigado pela companhia e pelas experiências vividas em Deus!

À CAPES, FAEPA e CNPq pelo auxílio financeiro para a realização deste trabalho. 
Só quem já provou a dor

Quem sofreu, se amargurou

Viu a cruz e a vida em tons reaís

Quem no certo procurou

Mas no errado se perdeu

Precisou saber recomeçar

Que overso tem reverso

Que o direíto tem o avesso

Que o de graça tem seu preço

Que a vida tem contráríos

E a saudade é um lugar

Que só chega quem amou

Eo ódio é uma forma tão estranha de amar

Só quem soube duvidar

Pôde enfim acreditar

Viu sem ver e amou sem aprísionar

Quem no pouco se encontrou

Aprendeu multiplicar

Descobriu o dom de eternizar
Só quem já perdeu na vida sabe o que é ganhar

Porque encontrou na derrota algum motivo para lutar

E assim viu no outono a prímavera

Descobriu que é no conflito que a vida faz crescer
Que o perto tem distâncias

Eo esquerdo tem direíto

Que a resposta tem pergunta

Eo problema, a solução

Eo amor começa aquí

No contrárío que há em mím

E a sombra só existe quando britha alguma luz.
Só quem perdoou na vida sabe o que é amar

Porque aprendeu que o amor só é amor

Se já provou alguma dor

E assim viu grandeza na miséría

Descobriu que é no limite

Que o amor pode nascer

(Contrários - Pe. Fábio de Melo) 


\section{SUMÁRIO}

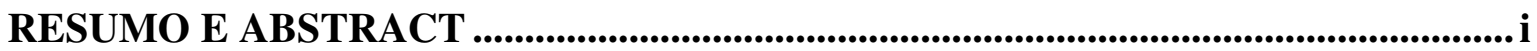

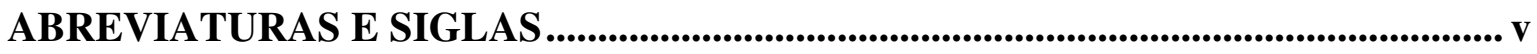

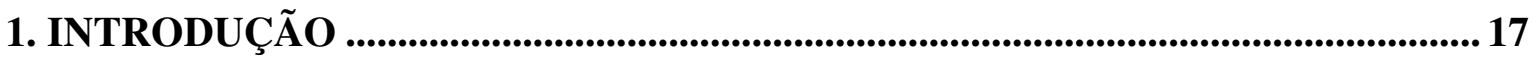

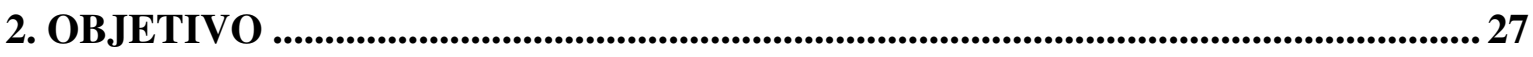

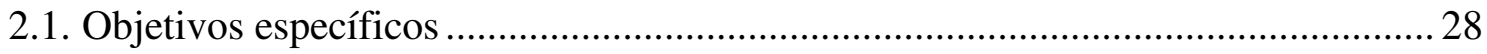

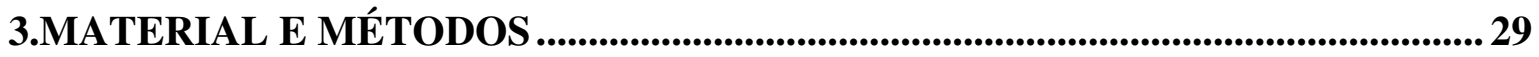

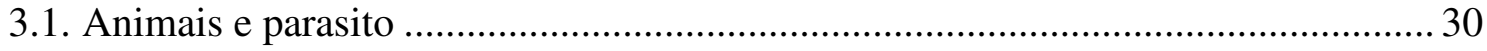

3.2. Infecção experimental e coleta de material ............................................................. 30

3.3. Determinação do parasitismo tecidual por PCR em tempo real ............................... 31

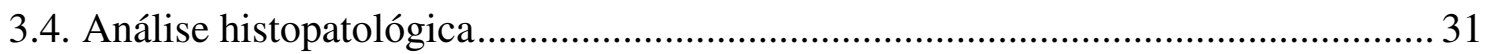

3.5. Análise do infiltrado inflamatório por citometria de fluxo................................... 32

3.6. Marcação de lipídeos com Sudão III .................................................................... 33

3.7. Determinação bioquímica de triglicérides e transaminases .................................... 33

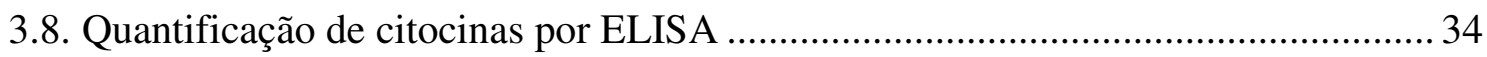

3.9. Extração de RNA total e confecção do DNA complementar ................................... 34

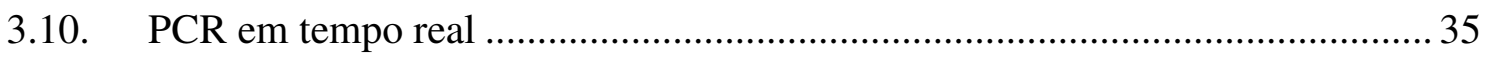

3.11. Administração de Gemfibrozil, agonista de PPAR $\alpha$......................................... 36

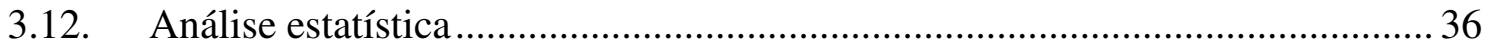

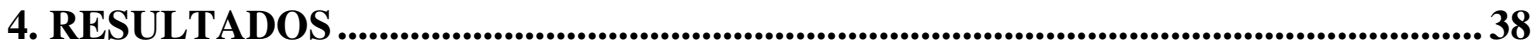

4.1. Expressão de transcritos de CCR5 e CCL4 em tecidos de camundongos C57BL/6

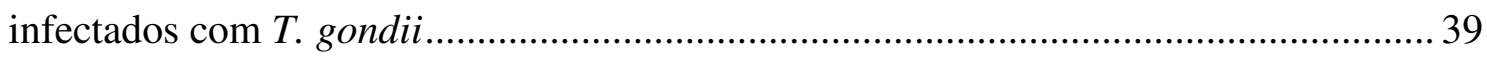

4.2. Sobrevida de camundongos $\mathrm{CCR}^{-/-}$e C57BL/6 infectados com T. gondii ............. 39

4.3. Parasitismo tecidual dos camundongos $\mathrm{CCR}^{-/-}$e C57BL/6 infectados................... 41

4.4. Análise histopatológica dos órgãos periféricos após a infecção.............................. 42

4.5. Infiltrado celular presente no intestino delgado............................................... 43

4.6. Caracterização macroscópica e marcação de lipídeos no fígado dos camundongos

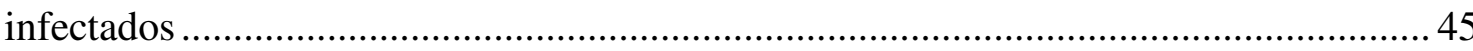


4.7. Dosagem de triglicérides e transaminases (ALT e AST) no soro dos camundongos infectados

4.8. Concentração de citocinas pró e anti-inflamatórias nos camundongos infectados.. 49

4.9. Expressão de RNA mensageiro nos camundongos infectados com $T$. gondii......... 53

4.10. Tratamento dos camundongos com agonista de PPAR $\alpha-$ Gemfibrozil ............57

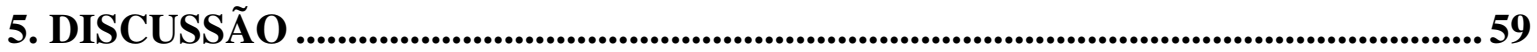

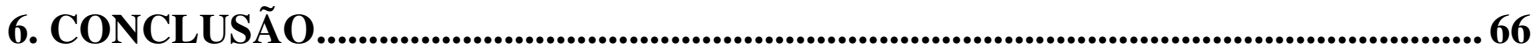

7. REFERÊNCIAS BIBLIOGRÁFICAS ....................................................................... 68

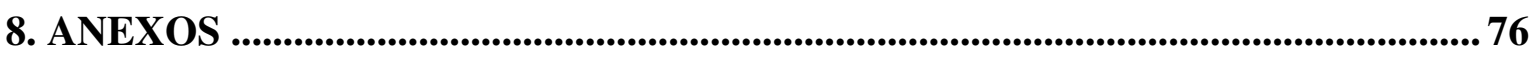

8.1. Parecer da comissão de ética em experimentação animal ....................................... 77 
RESUMOEABSTRACT 
BONFÁ, G. Papel de CCR5 na infecção oral por Toxoplasma gondii. 2010. 78f.

Dissertação de Mestrado - Faculdade de Medicina de Ribeirão Preto - FMRP/USP-SP.

Toxoplasma gondii é um protozoário intracelular obrigatório que causa a toxoplasmose. Em modelo experimental, camundongos C57BL/6 infectados por via oral com 100 cistos de $T$. gondii, cepa ME-49, desenvolvem sérias lesões intestinais similares as observadas em doenças inflamatórias intestinais. Ao invadir as células epiteliais intestinais, o parasito induz uma resposta inflamatória de padrão T "helper" (Th) 1 elevada, ativada pela produção de quimiocinas e citocinas envolvidas na migração e ativação celular. Para que ocorra essa migração celular para o sítio de infecção é necessário a presença de receptores de quimiocinas. O receptor de quimiocinas CCR5 é muito importante para o recrutamento celular em algumas infecções e está envolvido com a migração de vários subtipos celulares como células dendríticas, células $\mathrm{T}$ e, em particular, células $\mathrm{T}$ reguladoras. CCR5 pode estar relacionado também a mecanismos independentes da migração celular, no qual a sinalização

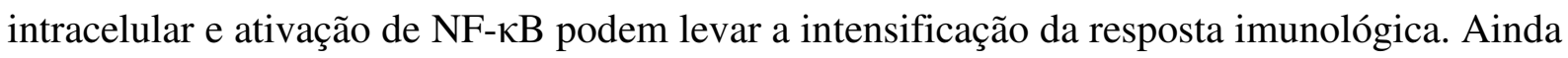
não está claro o papel do receptor CCR5 no modelo de infecção oral por T. gondii. Dessa forma, animais C57BL/6 e deficientes em CCR5 foram infectados por via oral com 5 cistos de T. gondii, cepa ME-49, e alguns parâmetros imunológicos e bioquímicos foram avaliados no $8^{\circ}$ dia de infecção. Os resultados mostraram que animais $\mathrm{CCR}^{-/-}$apresentaram alta suscetibilidade à infecção oral por $T$. gondii, exibindo um intenso infiltrado inflamatório no íleo e regiões de ulceração epitelial, quando comparados com animais C57BL/6. Independentemente de serem deficientes ou não de CCR5, os camundongos apresentaram focos inflamatórios dispersos pelo parênquima do fígado, entretanto camundongos $\mathrm{CCR} 5^{-/-}$ apresentaram uma extensiva vacuolização dos hepatócitos, com excessivo acúmulo de lipídeos no órgão e elevada concentração sérica de triglicérides e de transaminases. A carga parasitária foi significativamente mais elevada no intestino delgado e no fígado dos animais $\mathrm{CCR}^{-/-}$em comparação com animais C57BL/6. Foi observada também uma menor migração de células NK no intestino delgado, bem como um aumento na frequência de células T CD4 ${ }^{+}$ neste órgão e uma menor concentração de IFN- $\gamma$ e IL-12p40 no macerado do fígado dos animais $\mathrm{CCR}^{-/-}$em comparação com C57BL/6. Análise de expressão gênica no fígado revelou redução na formação de transcritos para PPAR $\alpha$ nos animais deficientes em CCR5, e quando os camundongos foram tratados com Gemfibrozil, um agonista de PPAR $\alpha$, houve reversão na vacuolização hepática e na concentração de triglicérides no soro dos animais 
$\mathrm{CCR}^{-/-}$. Estes dados sugerem que a migração celular dependente de CCR5 é essencial para a modulação da resposta inflamatória induzida por $T$. gondii no intestino delgado. Além do mais, a ausência de CCR5 compromete a integridade hepática durante a infecção oral por $T$. gondii e os mecanismos moleculares envolvidos podem estar relacionados à expressão de PPAR $\alpha$. 
BONFÁ, G. The role of CCR5 in oral infection by Toxoplasma gondii. 2010. 78f.

Dissertação de Mestrado - Faculdade de Medicina de Ribeirão Preto - FMRP/USP-SP.

T. gondii is an obligate intracellular protozoan parasite which is the causative agent of toxoplasmosis. In experimental model, C57BL/6 mice orally infected with a high parasitic load develop serious intestinal lesions, whose injuries are similar to those observed in Inflammatory Bowel Disease. This inflammation is caused due to parasite invasion of intestinal epithelial cells that elicit a robust Th1 type immune response. Moreover, chemokines produced by intestinal epithelial cells are involved in the migration and activation of inflammatory cells. In particular, the chemokine receptor CCR5 is important for cell recruitment in some infections and is involved with the migration of various cells subsets such as dendritic cells, T cells and, in particular regulatory T cells. CCR5 may also be related to mechanisms independent of cell migration, in which the intracellular signaling and activation of NF- $\kappa \mathrm{B}$ may lead to intensification of the immune response. The role of CCR5 has not been clear in the experimental oral T. gondii infection. Thus, wild type C57BL/6 mice and CCR5 $5^{-/-}$ littermates were infected with $T$. gondii by gavage and immune and biochemical parameters, were analyzed at day 8 after infection. The $\mathrm{CCR} 5^{-/-}$mice showed to be highly susceptible to the parasite, with intense inflammatory infiltration in the ilea and regions of epithelial ulcerations in comparison with WT mice. Both strain of mice presented inflammatory foci scattered by parenchyma of the liver, however the $\mathrm{CCR}^{-/-}$mice presented an extensive hepatocyte vacuolization with an excessive accumulation of lipids in the organ and elevated serum triglycerides and transaminases concentration. The parasite load was significantly higher on small intestine and liver samples of $\mathrm{CCR} 5^{-/-}$in comparison with WT mice. There was also a minor migration of NK cells in the small intestine, as well as greater frequency of $\mathrm{CD}^{+} \mathrm{T}$ cells in this organ and a lower IFN- $\gamma$ and IL-12p40 levels in liver homogenate samples in the $\mathrm{CCR}^{-/-}$mice compared with WT mice. Gene expression analysis revealed a reduction in the formation of transcripts for PPAR $\alpha$ in mice deficient in CCR5, and when the animals were treated with Gemfibrozil, a PPAR $\alpha$ agonist, there was an improvement in the level of vacuolization and reduced triglycerides. These data suggest that a CCR5-dependent cell migration is essential for the modulation of $T$. gondii-induced inflammatory response in the small intestine. In addition, hepatic integrity during $T$. gondii oral infection is compromised in the absence of CCR5, and the molecular mechanisms involved can be related to PPAR $\alpha$ expression. 
ABREVIATURASESIGLAS 


\section{ABREVIATURAS E SIGLAS}

AIDS - Síndrome da imunodeficiência adquirida

ALT - Alanina aminotransferase

AST - Aspartato aminotransferase

BSA - Fração V da albumina sérica bovina

CC - quimiocina CC

CCL2/MCP-1 - Proteína 1 quimiotática de monócito

CCL3/MIP-1 $\alpha$ - Proteína $1 \alpha$ inflamatória de macrófago

CCL4/MIP-1及 - Proteína $1 \beta$ inflamatória de macrófago

CCL5/ RANTES - Quimiocina expressa e secretada por células T normais e regulada após ativação

CCR - Receptor de quimiocina CC

$\mathbf{C C R 5}^{-/-}$- Camundongo geneticamente deficiente do receptor CCR5

CMC - Carboximetilcelulose

$\mathbf{C t}$ - "cycle threshold" - ciclo limiar

CXCL2/MIP-2 - Proteína 2 inflamatória de macrófago

CXCL10/IP-10 - Proteína induzível por IFN- $\gamma$

FLF - Falha fulminante do fígado, do inglês "Fulminat Liver Failure"

GEM - Gemfibrozil

GM-CSF - Fator estimulador de colônia de granulócito e macrófago

H\&E - Hematoxilina e Eosina

IBD - Doença inflamatória intestinal

IECs - Células epiteliais intestinais

IELs - Linfócitos epiteliais intestinais

IFN- $\boldsymbol{\gamma}$ - Interferon-gama

IL - Interleucina

iNOS - Óxido nítrico sintase induzível

LP - Lâmina própria

ME-49 - Cepa de baixa virulência de T. gondii, classificada no Tipo II

NK - Célula Natural Killer

NO - Óxido nítrico

PBS - Solução salina tamponada com fosfato 
PPAR - Receptores de proliferação de peroxissomos ativados, do inglês "Peroxissome Proliferator-Activated Receptors"

RPMI - Meio de cultura RPMI 1640

SBF - Soro bovino fetal

SNC - Sistema nervoso central

TGF- $\boldsymbol{\beta}$ - Fator de crescimento e transformação beta

T. gondii - Toxoplasma gondii

Th - Linfócito T "helper" (auxiliar)

TNF- $\boldsymbol{\alpha}$ - Fator de necrose tumoral alfa

VEI - Veículo (Carboximetilcelulose)

WT - "Wild type" - tipo selvagem - animais controle 
I . INTRODUCCÃO 


\section{INTRODUÇÃO}

Toxoplasma gondii é um protozoário intracelular obrigatório que pertence ao filo Apicomplexa, subclasse coccidia. Este parasito apresenta grande incidência entre aves e mamíferos, inclusive humanos, sendo sua ocorrência bem elevada e difundida pelo mundo. Estima-se que um terço da população do mundo esteja infectada por esse patógeno (MONTOYA; LIESENFELD, 2004). Nos Estados Unidos, cerca de 9\% dos indivíduos entre 12-49 anos são soropositivos para anticorpos contra este parasito (JONES et al., 2007). Na França, a estimativa de soroprevalência entre toda a população é alta, atingindo 60 a $70 \%$ (KASPER et al., 2004) e essa prevalência também é elevada nos países da América Latina, incluindo o Brasil, variando de 51 a 72\% (TENTER; HECKEROTH; WEISS, 2000). A doença causada por $T$. gondii é chamada toxoplasmose e tem emergido como uma das infecções oportunistas mais comuns em pacientes com AIDS (do inglês "acquired immune deficiency syndrome”), podendo ser fatal também ao feto durante a gestação. Desta forma, podemos observar seu destaque no cenário de saúde pública mundial (DUBEY; LINDSAY; SPEER, 1998).

A primeira descrição desse parasito foi em 1908, em dois países: na Tunísia, por Nicolle e Manceaux, de formas oriundas do roedor Ctenodactylus gundi e no Brasil, por Esplendore, de formas colhidas de coelhos doentes ou mortos "naturalmente" em laboratório. Em 1909 Nicolle e Manceaux classificaram o parasito e criaram o gênero Toxoplasma e a espécie T. gondii (KRICK; REMINGTON, 1978).

T. gondii apresenta três estágios infecciosos: o taquizoíta (do grego tachys = rápido; em grupos ou clones), forma que apresenta uma rápida proliferação na célula hospedeira, ocorrendo principalmente na fase aguda de infecção; o bradizoíta (do grego brady = lento, em cistos teciduais), forma que pela pressão imposta pela resposta imune encontra-se dentro de cistos sob replicação lenta na fase crônica de infecção; e o esporozoíta (contidos dentro dos oocistos liberados nas fezes de felídeos), que corresponde às formas infectantes oriundas do processo de reprodução sexuada do parasito (DUBEY; LINDSAY et al., 1998).

Membros da família dos felídeos, tais como o gato doméstico, são os únicos hospedeiros definitivos capazes de completarem todo o ciclo de vida de $T$. gondii, sendo os principais reservatórios de infecção. Hospedeiros intermediários são todos os animais homeotérmicos. Após a ingestão de cistos ou oocistos, os parasitos são liberados e diferenciam-se em taquizoítas que invadem as células epiteliais do intestino e iniciam uma 
fase assexuada de multiplicação, caracterizada pela produção de outros taquizoítas e alguns outros estágios intermediários de $T$. gondii. Em um desses estágios inicia-se o ciclo de vida sexuado do parasito, com a formação dos gametas femininos e masculinos. A fusão dos gametas produz o zigoto que secreta uma membrana cística rígida e este é eliminado com as fezes como oocisto não esporulado. Os oocistos eliminados não são imediatamente infectivos e após 1 a 5 dias de exposição ao ar e temperatura ambiente, ocorre a esporulação, produzindo dois esporocistos, cada um contendo quatro esporozoítos. Estes oocistos estáveis são altamente infecciosos quando ingeridos e podem permanecer viáveis no solo por até um ano ou mais, dependendo das condições favoráveis do ambiente (DUBEY; LINDSAY et al., 1998; COPPIN et al., 2003; MONTOYA; LIESENFELD, 2004; ALIBERTI, 2005).

A transmissão de $T$. gondii ocorre principalmente por via oral, sendo esta a via natural de infecção deste parasito. Esta se dá por meio da ingestão de carne crua ou mal cozida (principalmente de suínos e carneiros) contendo cistos do parasito ou através da ingestão de água ou alimentos contaminados com oocistos liberados nas fezes dos felídeos (MONTOYA; LIESENFELD, 2004; ALIBERTI, 2005). Outra via de infecção é a congênita, que pode ocorrer quando a mulher é infectada durante a gestação ou por reativação de infecção latente. Quando a transmissão vertical ocorre no primeiro trimestre da gestação, a toxoplasmose pode causar aborto, mortalidade neonatal e anormalidades fetais associadas principalmente com o sistema nervoso central (SNC) e retina (MONTOYA; LIESENFELD, 2004). A transmissão também pode ocorrer através de transplantes de órgãos de doadores soropositivos ou raramente por transfusão sanguínea ou acidente laboratorial (MONTOYA; LIESENFELD, 2004; ALIBERTI, 2005).

A fase aguda da toxoplasmose caracteriza-se pela ampla disseminação de $T$. gondii no organismo do hospedeiro, com multiplicação ativa dos taquizoítas no interior de células nucleadas. $\mathrm{Na}$ fase crônica, os parasitos permanecem viáveis na forma de cistos, principalmente nos músculos esquelético e cardíaco e no cérebro, nos quais podem permanecer durante toda a vida do hospedeiro (YAP; SHER, 1999). A evolução clínica da toxoplasmose adquirida é frequentemente benigna. Clinicamente, a infecção por $T$. gondii pode não ser notificada ou pode apresentar sinais e sintomas que vão depender do estado imunológico do indivíduo. Infecção primária em crianças e adultos (indivíduos imunocompetentes) normalmente é assintomática, porém algumas manifestações clínicas podem surgir como linfadenite e febre, acompanhada por astenia e mialgia. Uma pequena proporção de indivíduos, situação não muito frequente, pode apresentar miocardite, pneumonia, hepatite ou ainda encefalite (MONTOYA; LIESENFELD, 2004). 
Dentre as manifestações clínicas da toxoplasmose congênita, observa-se a hidrocefalia, microcefalia, calcificações intracranianas, corioretinite, estrabismo, cegueira, epilepsia, retardamento mental e psicomotor e anemia (MONTOYA; LIESENFELD, 2004). A principal alteração patológica resultante da toxoplasmose ocorre na fase crônica da doença quando a supressão do sistema imunológico, causada por drogas ou outras infecções, pode levar a reativação da infecção latente, resultado da ruptura do cisto e levando à necrose tecidual. Quando essa reação ocorre no SNC, é frequentemente fatal (ALIBERTI, 2005). Essa ocorrência é muito comum em indivíduos imunocomprometidos (como pacientes com AIDS) cujas manifestações clínicas incluem encefalite, alterações mentais, déficit motor, distúrbios nos nervos craniais, tontura, febre, entre outros sintomas (DUBEY; LINDSAY et al., 1998; MONTOYA; LIESENFELD, 2004).

A carga do inóculo, virulência do parasito, "background" genético, sexo e estado imunológico do hospedeiro afetam o curso da infecção em seres humanos e modelos animais (MONTOYA; LIESENFELD, 2004). A infecção que ocorre em camundongos é muito semelhante da que ocorre em humanos. Por essa razão, o modelo murino de infecção experimental por $T$. gondii é muito utilizado como ferramenta para o entendimento das alterações patológicas causadas por este parasito (DENKERS, 1999). Quando T. gondii infecta o hospedeiro pela via natural (ingestão de oocistos ou cistos teciduais), pode ser observado multiplicação do parasito na lâmina própria (LP) do intestino, levando ao desenvolvimento de desordens inflamatórias intestinais em algumas linhagens de camundongos. Em camundongos C57BL/6 infectados por via oral com 100 cistos da cepa ME-49 de T. gondii, observa-se letalidade de $100 \%$ dos animais, enquanto camundongos BALB/c sobrevivem com o mesmo inóculo (LIESENFELD et al., 1996). Esta alteração patológica compartilha características morfológicas e histológicas como as doenças inflamatórias intestinais (IBD, do inglês "Inflammatory Bowel Disease") em humanos, tais como a perda da arquitetura epitelial intestinal, influxo maciço de células inflamatórias na LP e focos de necrose. Essa resposta inflamatória exacerbada resulta em uma mortalidade precoce dos hospedeiros suscetíveis (LIESENFELD, 2002; KASPER; COURRET et al., 2004).

Quando o parasito é adquirido pela via oral, o taquizoíta invade ativamente as células epiteliais intestinais do hospedeiro (IECs, do inglês "Intestinal Epithelial Cells") e durante a invasão, ocorre a formação de um vacúolo parasitóforo, composto por moléculas do hospedeiro e do patógeno. Dentro deste vacúolo, o parasito divide-se por endodiogenia, um tipo especial de divisão celular, até romper a célula ou sair ativamente, infectando outras 
células vizinhas (NICHOLS; O'CONNOR, 1981). A infecção é disseminada via vasos linfáticos para os linfonodos, pelo sangue ao fígado e do fígado aos pulmões e a outros órgãos.

Com o adequado desenvolvimento da resposta imunológica a multiplicação de taquizoítas cessa. O parasito presente em certos tecidos, tais como o SNC e retina, se transformam em bradizoítas que sobrevivem dentro de cistos teciduais latentes, provocando pouca ou nenhuma reação inflamatória (DENKERS, 1999). As alterações patológicas associadas com encefalite toxoplásmica em camundongos imunocompetentes suscetíveis são caracterizadas pela presença de células inflamatórias nas meninges, manguitos perivasculares contendo plasmócitos, neutrófilos, linfócitos e macrófagos. Áreas de necrose podem também ser observadas, associadas com grande número de parasitos (HUNTER; REMINGTON, 1994).

Se a infecção não for controlada pelo sistema imune, os taquizoítas podem multiplicarse rapidamente e causar uma toxoplasmose generalizada e fatal (FRENKEL, 1988). A imunidade ao $T$. gondii é mediada por uma resposta imunológica celular específica, dependente principalmente da produção da interleucina 12 (IL-12) e citocina interferon gama (IFN- $\gamma$ ). Na fase aguda da infecção, o hospedeiro desencadeia mecanismos inatos de defesa que influenciam no desenvolvimento da resposta imune celular específica (DENKERS; GAZZINELLI, 1998). No início da infecção, T. gondii estimula macrófagos, células dendríticas e neutrófilos a liberarem IL-12 e o fator de necrose tumoral $\alpha$ (TNF- $\alpha$ ). A IL-12, por sua vez, induz células "Natural Killer" (NK) a produzirem IFN- $\gamma$, que age sinergicamente com TNF- $\alpha$, aumentando a atividade microbicida dos macrófagos (GAZZINELLI et al., 1994; BOURGUIN et al., 1998; BLISS; ZHANG; DENKERS, 1999) e induzem a proliferação de linfócitos T auxiliares $\left(\mathrm{CD}^{+}\right)$e $\mathrm{T}$ citotóxicos $\left(\mathrm{CD}^{+}\right)$, que produzem ainda mais IFN- $\gamma$. Essas células produtoras de IFN- $\gamma$ têm uma importante função na indução e manutenção do controle da infecção aguda e crônica por T. gondii (YAP; SHER, 1999).

Macrófagos infectados com T. gondii e ativados por IFN- $\gamma$ produzem óxido nítrico (NO), responsável pelo controle da replicação do parasito (ADAMS et al., 1990; LANGERMANS et al., 1992). Embora os mecanismos induzidos por IFN- $\gamma$ sejam potentes, não são completamente efetivos na eliminação dos parasitos (YAP; SHER, 1999). Alguns parasitos escapam do controle imunológico e sobrevivem no hospedeiro por longos períodos, continuando sua proliferação pelo organismo (ALIBERTI, 2005). As células T CD4 ${ }^{+}$e T $\mathrm{CD}^{+}$agem sinergicamente para prevenir a reativação do parasito durante o estágio crônico da 
infecção. E ainda, outros estudos indicam que células $\mathrm{T} \mathrm{CD}^{+}$são as principais células efetoras da imunidade protetora e que as células T CD4 ${ }^{+}$exercem importante papel auxiliar na ativação das células T CD8 ${ }^{+}$(GAZZINELLI et al., 1991).

Para confirmar a importância de células $\mathrm{T}$ em infecções com T. gondii, trabalhos anteriores demonstraram que camundongos C57BL/6 atímicos, assim como camundongos deficientes em células T $\mathrm{CD}^{+}$não desenvolvem necrose no íleo e sobrevivem mais do que os camundongos controles, embora apresentem grande número de parasitos no íleo. A alteração patológica e a necrose intestinal são dependentes de linfócitos $\mathrm{T} \mathrm{CD}^{+}$, do aumento das citocinas IFN- $\gamma$, TNF- $\alpha$ e da enzima óxido nítrico sintase induzível (iNOS) na mucosa intestinal dos camundongos suscetíveis ao T. gondii (LIESENFELD, 2002). Além disso, quando esses animais são tratados com anticorpo monoclonal contra TNF- $\alpha$ ou IFN- $\gamma$, observa-se a prevenção do desenvolvimento de necrose intestinal, indicando que ambas as citocinas, IFN- $\gamma$ e TNF- $\alpha$, estão envolvidas no desenvolvimento de necrose intestinal em camundongos C57BL/6 infectados com T. gondii (LIESENFELD et al., 1999). Um recente trabalho, no qual foi realizada uma análise histopatológica comparativa utilizando animais IFN- $\gamma^{-/-}$, TNFRp55 $^{-/-}$e iNOS ${ }^{-/}$, confirmou que IFN- $\gamma$ é essencial para indução da resposta inflamatória ao $T$. gondii bem como no controle do parasito nos estágios iniciais da infecção. Por outro lado, a ausência de iNOS ou a baixa expressão de iNOS combinado com ausência de TNFRp55 está associada a intensa resposta imune inflamatória e incapacidade do hospedeiro em eliminar o parasito (SILVA et al., 2009).

Outras citocinas também possuem um importante papel na indução de alterações imunopatológicas intestinais após a infecção oral por T. gondii. Quando camundongos C57BL/6 são tratados com anticorpos contra IL-12 e IL-18, após infecção com 100 cistos da cepa ME-49 de T. gondii, há prevenção no desenvolvimento da necrose intestinal (VOSSENKAMPER et al., 2004). Outro mecanismo que envolve a produção de citocinas importantes é a expressão de ciclofilina 18 (C18), uma proteína produzida pelo parasito que possui a capacidade de se ligar a CCR5 tanto em humanos quanto em camundongos (ALIBERTI et al., 2003), com afinidades comparáveis a de seu ligante prototípico CCL4

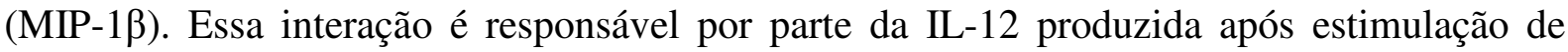
células dendríticas com antígeno solúvel de T. gondii (STAg) (ALIBERTI et al., 2000), pois quando estimulada apenas com C18, as concentrações de IL-12 são menores, podendo haver outros mecanismos de reconhecimento do parasito e indução de sinais, tais como aqueles observados por receptores do tipo Toll (TLR, do inglês "Toll-like receptors") (ALIBERTI; 
VALENZUELA et al., 2003).

Após a infecção oral por T. gondii e a invasão das IECs pelo parasito, podem ocorrer distúrbios fisiológicos e morfológicos. Essas células passam a secretar moléculas citotóxicas como NO, dando inicio a uma ação microbicida. Além disso, os enterócitos respondem à infecção pela secreção de várias quimiocinas (CCL2, CXCL2, CCL3 e CCL4) e citocinas (IL1, IL-6, IL-12, IL-15 e GM-CSF). Essas moléculas são essenciais para iniciar uma série de eventos imunológicos que levam a um robusto processo inflamatório no intestino por meio do recrutamento de vários tipos celulares do sistema imunológico, como neutrófilos, macrófagos e células dendríticas (MENNECHET et al., 2002; BUZONI-GATEL et al., 2006).

Amostras de intestino delgado infectado por T. gondii apresentam um aumento significativo na secreção da quimiocina, tais como proteína 1 quimiotática de monócito (MCP-1/CCL2) e, em menores proporções, proteína induzível por IFN- $\gamma$ (IP-10/ CXCL10), proteína $1 \alpha$ e $\beta$ inflamatória de macrófago (MIP-1 $\alpha$ e $\beta$ / CCL3 e CCL4), MIP-2/ CXCL2 e quimiocina regulada em ativação e normalmente expressa em célula T (RANTES/ CCL5) (MENNECHET; KASPER et al., 2002). Após a infecção, o número de células T CD4 ${ }^{+}$ aumenta e a produção de diferentes quimiocinas por células endoteliais e epiteliais no intestino infectado é importante para estabelecer um gradiente quimiotático para a migração de células T da circulação e para a produção de IFN- $\gamma$ que, juntamente com TNF- $\alpha$, aumenta a produção de quimiocinas, incluindo CXCL2, CCL2, CCL3 e CXCL10, ampliando a inflamação (MENNECHET; KASPER et al., 2002).

A expressão de quimiocinas pelo epitélio intestinal representa um importante mecanismo desse processo imunológico. Linfócitos intraepiteliais intestinais (IELs, do inglês "intraepithelial lymphocytes") expressam constitutivamente receptores de quimiocinas, tais como CCR9, CXCR3, CCR2 e CCR5 (ZABEL et al., 1999; KUNKEL et al., 2000). Esses receptores são muito importantes na migração celular durante a resposta imunológica, pois definem o perfil celular no processo inflamatório bem como o resultado final deste evento. Animais CCR2 $^{-/-}$são mais susceptíveis ao T. gondii, apresentando um elevado parasitismo em órgãos periférico e no SNC durante a fase aguda e no início da fase crônica no SNC, quando comparados aos animais controle. Da mesma forma, macrófagos do baço de animais deficientes em CCR2 não produzem NO suficiente para eliminar o parasito, demonstrando a importância de CCR2 na indução da expressão de iNOS e consequentemente produção de NO (BENEVIDES et al., 2008).

Camundongos C57BL/6 infectados com 35 cistos da cepa $76 \mathrm{~K}$ de $T$. gondii 
expressam quimiocinas CC e CXC no intestino delgado, incluindo CCL2, CCL3, CCL4, CCL5, CXCL2 e CXCL10, liberadas por enterócitos infectados que são responsáveis pelo recrutamento de IELs $\mathrm{CD}^{+}$. A migração para o intestino de linfócitos intraepiteliais $\mathrm{CD} 8 \beta^{+}$ induzida pela interação entre CCR5 nestes linfócitos e seus ligantes correspondentes CCL3 e CCL4 é essencial para o controle da resposta inflamatória exacerbada induzida pelo parasito, através da produção de TGF- $\beta$ (BUZONI-GATEL et al., 2001; LUANGSAY et al., 2003).

A expressão específica de receptores de quimiocinas por células T reguladoras (Tregs) favorece a migração dessas células tanto para tecidos linfóides como para tecidos periféricos. Dessa maneira, as quimiocinas CCL19 e CCL21, produzidas nos órgãos linfóides, induzem a migração de células capazes de expressar o receptor de CC quimiocina - CCR7; enquanto que outras quimiocinas como CCL3, CCL4 CCL17 e CCL22, produzidas em tecidos inflamados, levam ao acúmulo de células positivas para CCR4 ou CCR5 nestes sítios (IELLEM et al., 2001; COLANTONIO et al., 2002; LIM; HILLSAMER; KIM, 2004). Trabalhos recentes têm demonstrado também a importância de células Treg na infecção por $T$. gondii. Após a infecção oral com dose letal do parasito, o número e a frequência de células Treg Foxp $3^{+}$foi reduzido dramaticamente no sítio da infecção e sistemicamente. Além do mais, essas células passam a adquirir um fenótipo efetor durante a infecção, com aumentada expressão de T-bet e INF- $\gamma$, explicando assim o extenso quadro inflamatório intestinal observado e a consequente morte do hospedeiro (OLDENHOVE et al., 2009). Embora esforços sejam realizados para determinar a importância de células Treg durante a infecção por $T$. gondii, não está claro ainda quais fatores são determinantes para a localização dessas células no sítio de infecção.

CCR5 é expresso em células $\mathrm{T}$ não ativadas, de memória e efetoras, NKT, em monócitos, macrófagos e células dendríticas imaturas (SCHALL, 1991; SALLUSTO et al., 1999; APPAY; ROWLAND-JONES, 2001; MOTSINGER et al., 2002; THOMAS et al.,

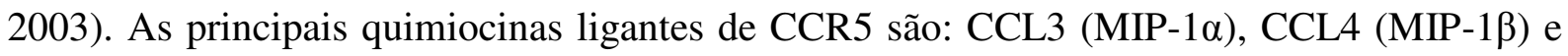
CCL5 (RANTES), as quais estão presentes em grande quantidade em tecidos inflamados como no líquido sinovial em pacientes com artrite inflamatória (LOETSCHER et al., 1998; WANG; LIU, 2003) ou no sistema nervoso central de camundongos com encefalomielite autoimune (BAGAEVA; WILLIAMS; SEGAL, 2003). Assim, a expressão de CCR5 em células T está relacionada tanto com a função pró ou anti-inflamatória e, embora tenha sido demonstrado que esse receptor é expresso durante a infecção por T. gondii (ALIBERTI; REIS E SOUSA et al., 2000), seu papel nessa doença não está claramente definido.

Recentemente, Moreira e colaboradores (2008) demonstraram que camundongos $\mathrm{CCR}^{-/-}$são capazes de controlar o crescimento e disseminação de leveduras de P. brasiliensis 


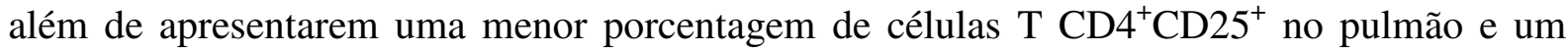
número menor de células Foxp $3^{+}$quando comparado ao camundongo selvagem, sugerindo assim, que CCR5 modula a migração e função supressora das células Tregs (MOREIRA et al., 2008). De forma interessante, camundongos deficientes de CCR5 são capazes de controlar a infecção por algumas bactérias como M. tuberculosis (ALGOOD; FLYNN, 2004) e Listeria monocytogenes (ZHONG et al., 2004), ou ainda o desenvolvimento de tumores (NG-CASHIN et al., 2003), sugerindo que sua ausência poderia limitar a migração das Treg em diferentes patologias. Outros trabalhos mostraram que CCR5 induz a migração de células T reguladoras naturais $\mathrm{CD}^{+} \mathrm{CD} 25^{+}$para o sítio de infecção por Leishmania major, onde participam do controle da resposta imunológica local e mantêm a sobrevivência do parasita por longos períodos no tecido do hospedeiro (YURCHENKO et al., 2006).

Como visto anteriormente, uma adequada imunoregulação é importante para prevenir as lesões provocadas pela infecção com T. gondii. Para comprovar tal fato, foi demonstrado que ambas citocinas, TGF- $\beta$ e IL-10, induzem efeitos anti-inflamatórios importantes na prevenção de necrose intestinal, sendo TGF- $\beta$ um potente agente imunorregulador (AHUJA et al., 1993). No intestino infectado por $T$. gondii, a composição de células infiltradas é representada pelos linfócitos $\mathrm{T} \mathrm{CD}^{+}$na $\mathrm{LP}$ e IELs $\mathrm{CD}^{+}$, que estão localizados entre as células epiteliais componentes principais da imunidade protetora contra $T$. gondii (MENNECHET; KASPER et al., 2002). A população de linfócitos T CD8 ${ }^{+}$isolada de camundongos infectados com $T$. gondii produz quantidades aumentadas de TGF- $\beta$. Esses linfócitos intraepiteliais interagem com os linfócitos $\mathrm{T} \mathrm{CD}^{+}$da $\mathrm{LP}$ e regulam negativamente a produção de IFN- $\gamma$, reduzindo a atividade proliferativa dessas células, efeitos ligados à produção de TGF- $\beta$ (MENNECHET et al., 2004).

Outra citocina importante na imunorregulação em infecções por T. gondii é a IL-10. Infecção oral com 20 cistos de T. gondii resulta em 100\% de mortalidade em animais deficientes em IL-10, mas não em animais controles (C57BL/6). Os animais deficientes em IL-10, infectados com $T$. gondii apresentaram alteração inflamatória grave no intestino. Estes resultados demonstram a importância de IL-10 no controle da patologia induzida pela infecção aguda com T. gondii (SUZUKI et al., 2000; KASPER; COURRET et al., 2004). Quando os camundongos IL-10 ${ }^{-/}$são tratados com anticorpo monoclonal contra IFN- $\gamma$, para examinar os efeitos na mortalidade, esses animais sobrevivem significativamente mais do que os camundongos controles tratados com IgG irrelevante. Esses resultados indicam que a produção de IFN- $\gamma$, na ausência de uma citocina reguladora, está diretamente relacionada ao desenvolvimento da necrose no intestino em camundongos IL-10 ${ }^{-/-}$(SUZUKI; SHER et al., 
2000). Assim, é de extrema importância estabelecer qual é o papel de CCR5 na imunorregulação e no controle da infecção por $T$. gondii para que se possa desenvolver estratégias mais elaboradas de imunointervenção em lesões causadas pela infecção com este parasito. 
2. OBJETIVO 


\section{OBJETIVO}

O objetivo deste estudo foi avaliar o papel do receptor de quimiocina CCR5 na resposta imunológica e no dano tecidual durante a infecção oral por Toxoplasma gondii.

\subsection{Objetivos específicos}

- Observar a presença de transcrito de RNA mensageiro para CCR5 bem como de seu ligante CCL4 no intestino delgado e no fígado de animais infectados com $T$. gondii;

- Determinar a susceptibilidade dos animais $\mathrm{CCR} 5^{-/}$após infecção oral com 5 cistos da cepa ME-49 de T. gondii;

- Analisar o parasitismo tecidual e alterações histopatológicas nos animais infectados com T. gondii;

- Determinar o fenótipo das células presentes no infiltrado celular do intestino delgado dos camundongos infectados;

- Identificar a lesão hepática nos animais $C C R 5^{-/-}$causada pela infecção com $T$. gondii;

- Determinar o perfil de citocinas pró e anti-inflamatórias local e sistêmico e o perfil de indução de transcrito para as quimiocinas CCL3 e CCL4, e de outras moléculas envolvidas;

- Avaliar a participação do receptor de quimiocina CCR5 e do receptor nuclear PPAR $\alpha$ na proteção dos hepatócitos e desenvolvimento de lesões hepáticas. 
3.MATERIALEMÉTODOS 


\section{MATERIAL E MÉTODOS}

\subsection{Animais e parasito}

Foram utilizados camundongos da linhagem C57BL/6 selvagens (WT) e animais geneticamente deficientes do receptor de quimiocina CCR5 $\left(\mathrm{CCR}^{-1-}\right)$, fêmeas de 7-10 semanas de idade. Todos os animais foram mantidos no biotério do Departamento de Bioquímica e Imunologia da Faculdade de Medicina de Ribeirão Preto/USP. Camundongos $\mathrm{CCR}^{-/-}$foram obtidos do laboratório Jackson (Bar Harbor, EUA). Todos os experimentos foram desenvolvidos de acordo com os Princípios Éticos na Experimentação Animal adotado pelo Colégio Brasileiro de Experimentação Animal (COBEA), aprovados pela Comissão de Ética em Experimentação Animal da Faculdade de Medicina de Ribeirão Preto - FMRP-USP (protocolo $\mathrm{n}^{\mathrm{o}}$ 200/2009).

Para realizar a infecção dos animais, foi utilizada a cepa ME-49 de T. gondii. A manutenção da cepa foi feita por inoculação intraperitoneal de 20 cistos de $T$. gondii em camundongos C57BL/6. Um mês após a inoculação, os cistos cerebrais foram coletados e homogeneizados em 2,0 mL de solução salina tamponada com fosfatado a $10 \mathrm{mM}$, pH 7,2 (PBS) estéril. Em seguida, os cistos foram contados e diluídos em solução de PBS. Para a infecção experimental, camundongos $\mathrm{C} 57 \mathrm{BL} / 6$ e $\mathrm{CCR}^{-/-}$foram infectados por via oral com 5 (cinco) cistos de T. gondii em um volume de $0,2 \mathrm{~mL}$.

\subsection{Infecção experimental e coleta de material}

Camundongos C57BL/6 e CCR5 $5^{-/-}$foram infectados por via oral com 5 cistos da cepa ME-49 de T. gondii. Para avaliar a sobrevida dos animais, dez camundongos de cada grupo foram infectados e a sobrevivência foi acompanhada durante 30 dias. Um grupo de 3 a 5 animais C57BL/6 e CCR5 ${ }^{-/-}$foi infectado e no dia 8 de infecção o sangue foi coletado por meio de punção do plexo retro-orbital para obtenção do soro e, em seguida, os animais foram eutanasiados por deslocamento cervical. Após a eutanásia, os órgãos (sistema nervoso central (SNC), pulmão, fígado, baço e intestino delgado) foram coletados, fragmentados e acondicionados em formas diferentes dependendo do destino final. 


\subsection{Determinação do parasitismo tecidual por PCR em tempo real}

Para a quantificação da carga parasitária nos órgãos dos animais infectados, fragmentos do fígado e intestino delgado foram coletados no $8^{\circ}$ dia de infecção e armazenados em tubo seco à $-70^{\circ} \mathrm{C}$. A extração de DNA total tecidual foi realizada com o Kit illustra $^{\mathrm{TM}}$ Tissue \& Cells GenomicPrep (GE Healthcare, Freiburg, Alemanha), onde 25-30 mg do tecido foi pesado e fragmentado com o auxílio de um bisturi. Logo após, o tecido foi submetido à lise com tampões específicos do Kit e digestão com proteinase K. Neste processo de extração foi utilizado também RNase A para minimizar contaminação de RNA no material e o DNA purificado foi eluído da coluna de sílica em $100 \mu \mathrm{L}$ de tampão de eluição fornecido no kit. O DNA foi quantificado em um espectrofotômetro (Thermo Scientific NanoDrop ${ }^{\mathrm{TM}}$ 1000) e 100 ng foram utilizados para estimativa da carga parasitária. A quantificação foi realizada por meio da reação da polimerase em cadeia em tempo real (PCR tempo real) na metodologia SYBR Green (Invitrogen Life Technologies, Carlsbad, EUA). A reação foi submetida ao Sistema de Detecção de Sequência ABI 7000 (Applied Biosystem, Warrington, Reino Unido) com os seguintes parâmetros de ciclagem: 2 minutos a $50^{\circ} \mathrm{C}, 2$ minutos a $95^{\circ} \mathrm{C}$, e quarenta ciclos de 15 segundos a $95^{\circ} \mathrm{C}, 30$ segundos a $58^{\circ} \mathrm{C}$ e 30 segundos a $72^{\circ} \mathrm{C}$, além de um passo de dissociação, com temperatura variando de 60 a $95^{\circ} \mathrm{C}$. A sequência dos oligonucleotídeos utilizada para amplificação, cujo alvo foi o gene B1 de Toxoplasma gondii foi: Senso 5'-TTC AAG CAG CGT ATT GTC GA-3' e Antisenso 5'-CAT GAA CGG ATG CAG TTC CT-3'(MWG Oligo Synthesis Report). Os resultados foram obtidos com auxílio de uma curva padrão feita com concentrações graduais de DNA purificado do parasito.

\subsection{Análise histopatológica}

Para observação da morfologia e alterações patológicas nos diferentes órgãos dos animais infectados, fragmentos de SNC, pulmão, fígado e intestino delgado foram coletados no $8^{\circ}$ dia de infecção, fixados em formol tamponado a 10\% e, após 24 horas, desidratados em concentrações crescentes de álcool e xilol. Posteriormente, os fragmentos foram incluídos em parafina e cortes de $5 \mu \mathrm{m}$ de espessura dos tecidos foram obtidos com o auxílio de um micrótomo. Os cortes foram dispostos em lâminas e incubados a $60^{\circ} \mathrm{C}$ para fixação. Em seguida foram lavados em xilol para retirar o excesso de parafina e hidratados com concentrações decrescentes de álcool (do absoluto ao álcool 70\%). Os cortes foram então corados com Hematoxilina e Eosina (H\&E), desidratados com concentrações crescentes de 
álcool (de $70 \%$ ao absoluto), lavados com xilol e montados em lamínula e Bálsamo do Canadá (Vetec Química, Rio de Janeiro, Brasil).

Para análise das lesões patológicas induzidas por T. gondii no intestino delgado, este foi coletado e lavado em PBS para retirada das fezes. Após a lavagem, o intestino foi seccionado em quatro partes: duodeno, jejuno proximal, jejuno distal e íleo. Esses fragmentos foram então enrolados individualmente em um "rolo suíço" e processados como descrito anteriormente. As imagens foram obtidas em microscópio ótico e as análises comparativas foram descritas por um patologista.

\subsection{Análise do infiltrado inflamatório por citometria de fluxo}

Com o intuito de caracterizar o infiltrado celular dos animais infectados com 5 cistos de T. gondii, o intestino delgado foi coletado no $8^{\circ}$ dia de infecção de camundongos WT e $\mathrm{CCR}^{-/-}$e os leucócitos presentes foram isolados e determinados de acordo com a expressão dos seguintes marcadores: CD3, CD4, CD8, CD19,CD25, Foxp3 e NK1.1, identificados por anticorpos conjugados a PE, FITC, PerCP, PE-Cy5 e PE-Cy7 (BD Bioscience, San Diego, EUA).

Para obtenção dos leucócitos no intestino delgado, foi usado o método descrito por GUY-GRAND (1978) com algumas modificações (GUY-GRAND; GRISCELLI; VASSALLI, 1978). Resumidamente, a extração foi dividida em dois processos: extração dos linfócitos intraepiteliais (IELs) e da lâmina própria (LP). Para isolar os IELs, segmentos do intestino delgado foram lavados com PBS, abertos e cortados em pedaços pequenos. A mucosa foi então dissociada com solução de RPMI-1640 (GIBCO, Nova York, EUA) contendo $10 \%$ de soro fetal bovino (SBF) e 1,0 mM de ditiotreitol (DTT). Após centrifugação, as células foram suspensas em PBS contendo 10\% de SBF, passadas em uma coluna de lã de nylon e purificadas em um gradiente de Ficoll-Paque ${ }^{\mathrm{TM}}$ Plus (GE Healthcare, Suécia). O número de células obtidas foi quantificado em câmara de Neubauer. Para isolar os linfócitos da LP, fragmentos do intestino delgado foram cortados em pequenos pedaços em solução PBS contendo $3 \mathrm{mM}$ de EDTA e agitados por 20 minutos. Após este período, as células foram centrifugadas e o sobrenadante descartado. Foi adicionado solução RPMI-1640 com $1 \%$ de SBF, $1 \mathrm{mM}$ de EGTA e $1,5 \mathrm{mM}$ de $\mathrm{MgCl}_{2}$ ao sedimento e, após agitação, foi adicionado liberase para digestão tecidual. Em seguida, as células foram passadas em lã de nylon e purificadas em gradiente Ficoll. 
Em geral, as células extraídas do infiltrado inflamatório foram lavadas e ressuspensas em PBS - BSA a $1 \%$ na concentração de $1 \times 10^{6}$ células $/ \mathrm{mL}$. Em seguida, foram adicionados $100 \mu \mathrm{L}$ de Fc block (BD Bioscience) e a suspensão foi incubada por 30 minutos a $25^{\circ} \mathrm{C}$. Após este tempo foram adicionados anticorpos marcados específicos para moléculas de superfície descritas acima. Os tubos foram incubados por 30 minutos a $4^{\circ} \mathrm{C}$. As células foram lavadas com PBS por 10 minutos a 500 x g e aquelas com marcação de superfície foram fixadas com $100 \mu \mathrm{L}$ de PBS - formol a 1\%. Para marcação intracelular (Foxp3), às células correspondentes foram adicionados $100 \mu \mathrm{L}$ de Cytofix/Cytoperm ${ }^{\mathrm{TM}}$ (BD Bioscience) para fixação e permeabilização celular por 15 minutos. As células foram então lavadas com $1 \mathrm{~mL}$ de Perm/Wash ${ }^{\mathrm{TM}}$ (BD Bioscience) 10 minutos a $500 \mathrm{x}$ g, o sobrenadante foi descartado e foi adicinado mais $100 \mu \mathrm{L}$ de Perm/Wash ${ }^{\mathrm{TM}}$. Os anticorpos foram adicionado e incubado por 30 minutos no escuro. A reação foi então lavada com $1 \mathrm{~mL}$ de Perm/Wash ${ }^{\mathrm{TM}}$ e fixada com 100 $\mu \mathrm{L}$ de PBS - formol a 1\%. A aquisição das células foi realizada em citômetro de fluxo (FACSCantoII - BD Bioscience) e a analizadas pelo software FlowJo (Tree Star). O número absoluto dos leucócitos específicos obtidos dos órgãos dos animais foi calculado proporcionalmente em relação ao número de células totais obtidas a partir da contagem em câmara de Neubauer.

\subsection{Marcação de lipídeos com Sudão III}

Para identificar a presença de lipídeos no fígado dos camundongos C57BL/6 e CCR5 ${ }^{-1-}$ infectados com $T$. gondii, o órgão dos animais no $8^{\circ}$ dia de infecção foi coletado e congelado em meio OCT (Sakura Finetek Inc., Torance, EUA). Para realizar a marcação, cortes de $5 \mu \mathrm{m}$ de espessura foram obtidos com o auxílio de um criostato. Após a confecção, as lâminas foram fixadas em formol tamponado a $10 \%$ por 10 minutos, submergidas em álcool a $70 \%$ por 3 minutos, coradas com solução Vermelho Sudan III (Merck KGaA, Darmstadt, Alemanha) por 3 minutos, lavadas em álcool a $70 \%$ e em água corrente e contracoradas em hematoxilina por 1 minuto. As lâminas foram montadas com lamínula em meio aquoso contendo glicerina e gelatina. A análise das lâminas foi feita em microscópio óptico no qual lipídeos neutros são corados em vermelho vivo e ésteres de colesterol ficam alaranjados.

\subsection{Determinação bioquímica de triglicérides e transaminases}

Para avaliar a magnitude da lesão no fígado destes animais infectados com $T$. gondii, o soro de camundongos C57BL/6 e $\mathrm{CCR}^{-/-}$com 8 dias de infecção foi submetido a um ensaio 
para dosagem de triglicérides e da atividade de duas enzimas relacionadas ao dano hepático: transaminase pirúvica (ALT ou TGP) e transaminase oxaloacética (AST ou TGO). A concentração sérica de triglicérides foi determinada por método colorimétrico enzimático pela metodologia Enzimático-Trinder (TRINDER, 1969) com Kit, seguindo as normas do fabricante (LabTest, Minas Gerais, Brasil). As concentrações de ALT e AST no soro foram determinadas por método colorimétrico pela reação de Reitman Frankel (BURTIS \& ASHWOOD, 2001), seguindo as normas do fabricante (LabTest). A reação de TG resulta da ação enzimática que culmina na formação de uma quinoneimina que tem máximo de absorbância em $505 \mathrm{~nm}$. Já a reação de AST resulta na formação de oxalacetato, que é medido através da formação de hidrazona, a qual tem intensa cor em meio alcalino enquanto ALT resulta na formação de piruvato, que é medido também através da formação de hidrazona, a qual tem intensa cor em meio alcalino e máxima absorbância em $505 \mathrm{~nm}$.

\subsection{Quantificação de citocinas por ELISA}

Para analisar a produção sistêmica e local de citocinas em resposta à infecção por $T$. gondii, o sangue, fígado e íleo de animais C57BL/6 e CCR5 ${ }^{-/-}$infectados foram coletado no $8^{\circ}$ dia de infecção. O soro foi preparado por centrifugação do sangue dos animais a 3000 x g por 10 minutos a temperatura ambiente e posteriormente armazenado a $-20^{\circ} \mathrm{C}$ até o momento do uso. Para preparação do macerado, os tecidos foram coletados, pesados e homogeneizados em solução com inibidores de protease Complete (Roche, Alemanha). Em seguida, foi realizada uma centrifugação a $300 \mathrm{x}$ g por 10 minutos a $4^{\circ} \mathrm{C}$ e o sobrenadante foi coletado e armazenado a $-70^{\circ} \mathrm{C}$. As concentrações das citocinas IL-12p40, IFN- $\gamma$, TNF- $\alpha$, TGF- $\beta$ e IL10 presentes no soro e no macerado tecidual dos animais foram quantificadas pelo método imunoenzimático (ELISA), utilizando kits comerciais da OpTEIA, BD Biosciences (San Diego, EUA), seguindo as normas do fabricante. A concentração das citocinas nas amostras foi calculada a partir da curva padrão de cada citocina recombinante. A leitura das placas foi feita em leitor de microplacas por absorbância a $495 \mathrm{~nm}$.

\subsection{Extração de RNA total e confecção do DNA complementar}

O RNA foi extraído de fragmentos do fígado e íleo dos animais WT e CCR5 ${ }^{-/}$, coletados no $8^{\circ}$ dia de infecção com $T$. gondii para determinar a transcrição de alguns genes por PCR em tempo real. O RNA total foi extraído por um método que combinou TRIzol (Invitrogen) seguida da utilização parcial do Kit de extração illustra RNAspin Mini (GE 
Healthcare, Alemanha). O tecido foi coletado em TRIzol (500 $\mu \mathrm{L} / 100 \mathrm{mg}$ de tecido) e acondicionado a $-70^{\circ} \mathrm{C}$ até o momento da extração. Ao extrair, o tecido foi descongelado e triturado com homogenizador seguido da adição de mais $500 \mu \mathrm{L}$ de TRIzol e incubação de $~ 5$ minutos a temperatura ambiente. Após a adição de $200 \mu \mathrm{L}$ de clorofórmio, o macerado foi misturado por agitação durante 15 segundos e centrifugado a 10000 x g por 10 minutos a $4^{\circ} \mathrm{C}$. A fase aquosa superior foi utilizada como material para o Kit de extração RNAspin Mini e o RNA foi isolado de acordo com as normas do fabricante. Após a extração, o RNA foi determinado quanto a quantidade, pureza e qualidade usando um espectrofotômetro (Thermo Scientific NanoDrop $\left.{ }^{\mathrm{TM}} 1000\right)$.

O RNA purificado foi submetido à confecção do DNA complementar (cDNA) com a enzima Transcriptase Reversa SuperScript ${ }^{\mathrm{TM}} \mathrm{III}$ (Invitrogen), onde foram adicionados $1 \mu \mathrm{L}$ de Oligo(dT) ${ }_{12-18}, 1 \mu \mathrm{L}$ de mix de dNTP 10 mM, $2 \mu \mathrm{g}$ do RNA extraído e $\mathrm{H}_{2} \mathrm{O}$ destilada para 14 $\mu \mathrm{L}$ de volume final para cada reação. A reação foi incubada a $65^{\circ} \mathrm{C}$ por 5 minutos em termociclador PTC-100 (MJ Research, Watertown, EUA ) seguida de incubação no gelo por 1 minuto. Em seguida, foram adicionados a reação mix contendo $4 \mu \mathrm{L}$ de tampão, $1 \mu \mathrm{L}$ de DTT $0,1 \mathrm{mM}$ e $1 \mu \mathrm{L}$ da enzima Transcriptase Reversa SuperScript ${ }^{\mathrm{TM}}(200 \mathrm{U} / \mu \mathrm{L})$, totalizando 20 $\mu \mathrm{L}$ de volume final de reação. A reação foi então prosseguida com incubação de $50^{\circ} \mathrm{C}$ por 60 minutos e inativação com $70^{\circ} \mathrm{C}$ por 15 minutos. $\mathrm{O}$ cDNA confeccionado foi então diluído 8 vezes, adicionando-se $140 \mu \mathrm{L}$ de $\mathrm{H}_{2} \mathrm{O}$ destilada estéril ao volume final após a reação.

\subsection{PCR em tempo real}

A análise relativa de transcritos de genes de citocinas, quimiocinas, fatores de transcrição e receptores de quimiocinas foi realizada com cDNA confeccionado a partir do RNA extraído do fígado e do íleo de animais C57BL/6 e CCR5 ${ }^{-/}$infectados oralmente com 5 cistos de T. gondii no $8^{\circ}$ dia de infecção. A reação de PCR em tempo real (qPCR) foi realizada com 6,5 $\mu \mathrm{L}$ de SYBR Green Mix (Invitrogen), 0,5 $\mu \mathrm{L}$ de cada primer (senso e antisenso) a $10 \mu \mathrm{M}, 5 \mu \mathrm{L}$ do cDNA sintetizado a partir de $2 \mu \mathrm{g}$ de RNA extraído e $\mathrm{H}_{2} \mathrm{O}$ destilada estéril suficiente par volume final de $15 \mu \mathrm{L}$. A reação foi submetida ao aparelho ABI PRISM - 7000 "Sequence Detection System” (Applied Biosystems, EUA) e compreendeu 2 minutos a $50{ }^{\circ} \mathrm{C}, 2$ minutos a $95^{\circ} \mathrm{C}$, e quarenta ciclos de 15 segundos a $95^{\circ} \mathrm{C}, 30$ segundos a $58^{\circ} \mathrm{C}$ e 30 segundos a $72^{\circ} \mathrm{C}$. Nas reações com o SYBR Green, um ciclo final de 20 minutos com temperatura crescente de 60 a $95{ }^{\circ} \mathrm{C}$ foi empregado para a obtenção de uma curva de dissociação dos produtos da reação, utilizada para a análise da especificidade de amplificação. 
Todas as amostras foram corridas em duplicadas e os resultados foram normalizados com GAPDH e analisados com base no valor de $\mathrm{Ct}$ (cicle threshold) ou linha de corte. O resultado foi calculado com a fórmula $\Delta \Delta \mathrm{Ct}=\Delta \mathrm{Ct}$ amostra $-\Delta \mathrm{Ct}$ amostra controle, onde $\Delta \mathrm{Ct}=\mathrm{Ct}$ gene estudado - Ct GAPDH. O número de vezes de expressão diferencial do mRNA comparado com o controle foi definido pela fórmula do $2^{-\Delta \Delta \mathrm{Ct}}$. Os "primers" e sequências utilizados durante a reação de PCR em tempo real estão listados na Tabela 1.

Tabela 1 - Relação de primers e sequências utilizadas

\begin{tabular}{|c|c|c|}
\hline \multirow{2}{*}{ Gene } & \multicolumn{2}{|c|}{ Sequências } \\
\hline GAPDH & Senso & Antisenso \\
\hline CCL3 & 5'-TGCAGTGGCAAAGTGGAGAT-3' & 5'-CGTGAGTGGAGTCATACTGGAA-3' \\
\hline CCL4 & 5'-TTCTGCTGACAAGCTCACCCT-3' & 5'-ATGGCGCTGAGAAGACTTGGT-3' \\
\hline CCL5 & 5'-CCTGACCAAAAGAGGCAGACA-3' & 5'-AGCAAGGACGCTTCTCAGTGA-3' \\
\hline CCR5 & 5'-TTCCCTGTCATCGCTTGCTCT-3' & 5'-CGGATGGAGATGCCGATTTT-3' \\
\hline IL-12p40 & 5'-TGCACAAAGAGACTTGAGGCA-3' & 5'-AGTGGTTCTTCCCTGTTGGCA-3' \\
\hline IL-17 & 5'-AGCACCAGCTTCTTCATCAGG-3' & 5'-GCGCTGGATTCGAACAAAG-3' \\
\hline iNOS & 5'-TGCCCTCCACAATGAAAAGA-3' & 5'-AACACGAAGCAGTTTGGGAC-3' \\
\hline PPAR $\alpha$ & 5'-CGAAACGCTTCACTTCCAA-3' & 5'-TGAGCCTATATTGCTGTGGCT-3' \\
\hline PPAR $\gamma$ & 5'-TCAATGCCTTAGAACTGGATGA-3' & 5'-CCGATCTCCACAGCAAATTATA-3' \\
\hline ROR- $\gamma$ ' & 5'-TGAGATCATCTACACGATGCTG-3' & 5'-AGGAACTCCCTGGTCATGAA-3' \\
\hline Foxp3 & 5'-TGGAAGATGTGGACTTCGTTT-3' & 5'-TGGTTCCCCAAGTTCAGGAT-3' \\
\hline
\end{tabular}

\subsection{Administração de Gemfibrozil, agonista de PPARa}

Para administração de Gemfibrozil (Gem) (Sigma-Aldrich, St. Louis, EUA), uma solução estoque a $100 \mathrm{mg} / \mathrm{ml}$ foi preparada por dissolver este fármaco em etanol puro. A solução estoque foi diluída em carboximetilcelulose (CMC) a 0,75\% e os animais C57BL/6 e $\mathrm{CCR}^{-/-}$infectados com 5 cistos de $T$. gondii foram tratados por via oral durante 7 dias, a partir do primeiro dia de infecção, com $100 \mathrm{mg} / \mathrm{kg} /$ dia do fármaco em volume total de 200 $\mu \mathrm{L}$. Animais controle infectados foram tratados com equivalente quantidade de etanol e veículo CMC. Para avaliar os parâmetros bioquímicos e histopatológicos, o fígado e o sangue dos animais foram coletados e acondicionados de acordo com cada experimento.

\subsection{Análise estatística}

A curva de Kaplan-Meier foi utilizada para comparar a sobrevivência dos grupos de animais estudados e os dados de mortalidade dos grupos experimentais foram analisados pelo 
teste Qui-quadrado $\left(\chi^{2}\right)$. A análise de parasitismo tecidual e as concentrações de enzimas foram comparadas usando o teste $t$ de Student's bicaudal: duas amostras presumindo variâncias equivalentes. O teste de ANOVA com pós-teste de Tukey foi empregada para análise de citocinas. A análise estatística e os gráficos foram realizados utilizando o software GraphPad Prism versão 5.0 (GraphPad Software, San Diego, EUA). Os valores foram expressos como média \pm erro padrão da média (SEM). Todos os valores foram considerados significativos quando $P<0.05$. 
4. Resultados 


\section{RESULTADOS}

\subsection{Expressão de transcritos de CCR5 e CCL4 em tecidos de camundongos C57BL/6 infectados com $T$. gondii}

A migração ou recrutamento de células da resposta imunológica para os sítios de infecção com T. gondii é essencial como mecanismo de defesa do hospedeiro para combater o patógeno. Essa migração pode ocorrer mediante interação quimiocina-receptor, por meio de um gradiente de quimiocinas produzido no local da infecção. Uma vez que o receptor de quimiocinas CCR5 está intimamente ligado com o recrutamento de diferentes tipos celulares para os tecidos periféricos, analisamos inicialmente a presença de transcrito para CCR5 e seu principal ligante, CCL4/MIP-1 $\beta$, no íleo e no fígado de camundongos C57BL/6 infectados com $T$. gondii no $8^{\circ}$ dias após a infecção.

A análise da presença de transcrito para CCR5 e para CCL4 demonstrou que, além das células presentes no íleo e no fígado possuírem transcrito para CCR5 (figura 1A) e CCL4 (figura 1B), elas são induzidas a produzir mais CCR5 e CCL4 mediante infecção com $T$. gondii. Foi possível observar também que a quimiocina CCL4 foi mais induzida no fígado do que no íleo dos animais infectados (Figura 1B), sugerindo assim seu importante papel no recrutamento de células para este órgão. Esses dados de expressão de mensagem de CCR5 após infecção por $T$. gondii sugerem que células $\mathrm{CCR} 5^{+}$estejam migrando para os tecidos analisados ou que as células presentes nestes locais de infecção são induzidas a expressar este receptor e seu ligante principal, durante a fase aguda de infecção com $T$. gondii.

\subsection{Sobrevida de camundongos $\mathrm{CCR5}^{-/-}$e C57BL/6 infectados com $T$. gondii}

Para determinar o papel de CCR5 na infecção oral por T. gondii, animais C57BL/6 e $\mathrm{CCR}^{-/-}$foram infectados por via oral com 5 cistos da cepa ME-49 de T. gondii e inicialmente foram avaliados quanto a sobrevida. Para realizar este experimento, foram utilizados 10 camundongos fêmea por grupo e a mortalidade foi monitorada até 30 dias após a infecção. Com esse inóculo, os animais C57BL/6 apresentaram 70\% de sobrevida até o $30^{\circ}$ dias de infecção. Porém, os animais $\mathrm{CCR} 5^{-/-}$apresentaram uma acentuada mortalidade na fase aguda da infecção pelo parasito $\left(\chi^{2}=14,39 ; \mathrm{P}=0,0001 ; \mathrm{df}=1\right)$, com início no $8^{\circ}$ dia após a infecção e todos animais $\mathrm{CCR} 5^{-/-}$sucumbiram até o $16^{\circ}$ dia após a infecção (Figura 2). Esses resultados indicam que os animais $\mathrm{CCR} 5^{-/-}$são altamente suscetíveis à infecção oral por T. gondii. 
A

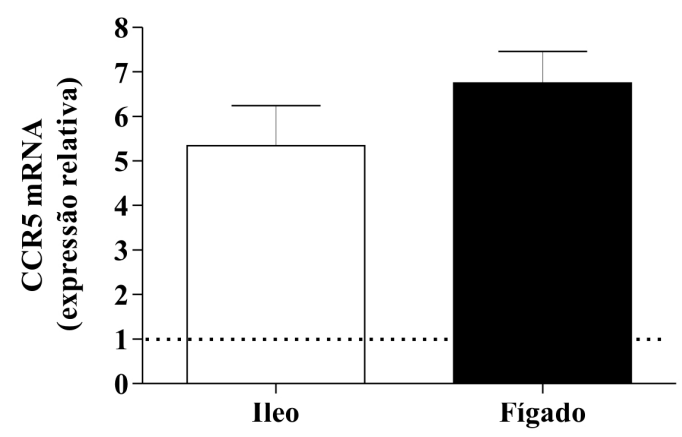

B

CCL4

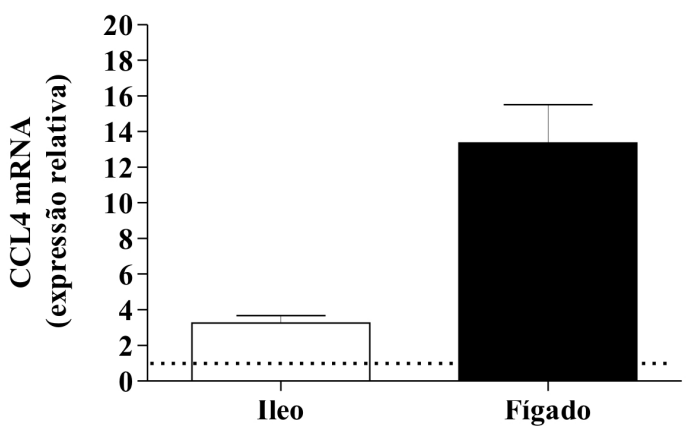

Figura 1. Expressão de transcrito de RNA mensageiro para CCR5 e CCL4 no íleo e no fígado de camundongos C57BL/6 infectados com T. gondii. Camundongos C57BL/6 foram infectados por via oral com 5 cistos da cepa ME-49 de T. gondii e no $8^{\circ}$ dia após a infecção foram coletados íleo e fígado para extração de RNA e confecção do cDNA. Foram utilizados "primers" específicos para CCR5 (A) e CCL4 (B) em uma reação de qPCR e os dados foram normalizados para o gene de referência GAPDH. Os valores de $\mathrm{Ct}$ (do inglês "cycle threshold") foram analisados pela fórmula $2^{-\Delta \Delta \mathrm{Ct}}$, como demonstrado em material e métodos, no qual o valor 1 foi adotado como referencial relativo aos animais controle não infectados. Os resultados foram obtidos com 4 animais por grupo.

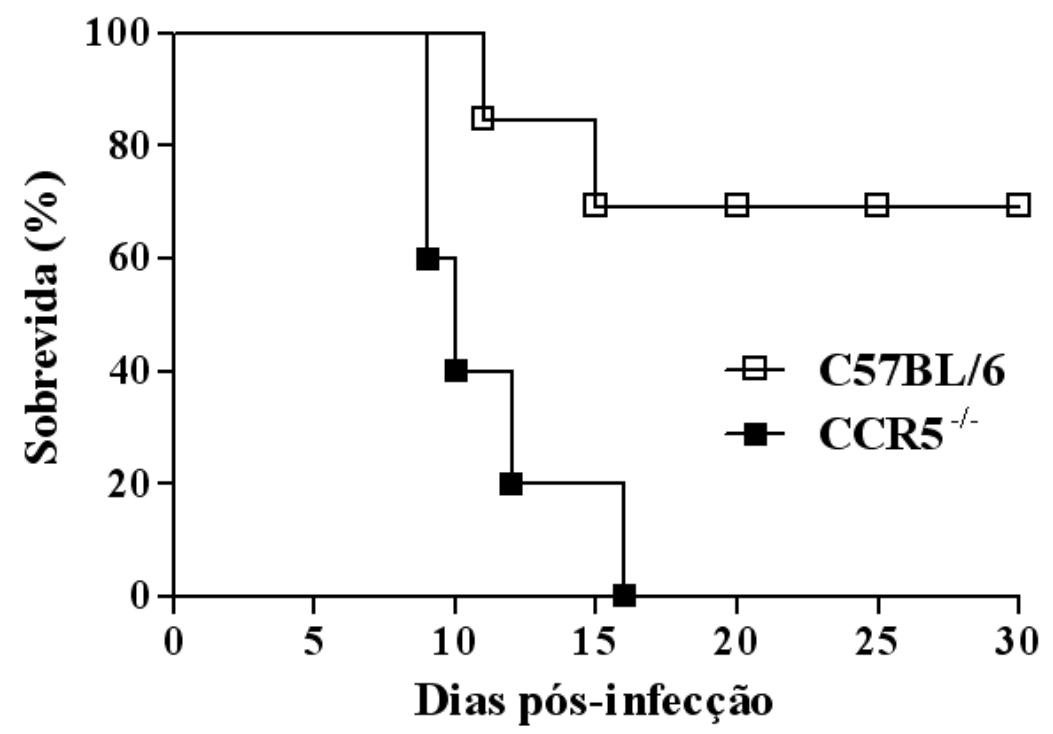

Figura 2. Sobrevida de camundongos C57BL/6 e $\mathrm{CCR5}^{-/-}$após infecção oral com T. gondii. Camundongos C57BL/6 e CCR5 ${ }^{-/}$foram infectados por via oral com 5 cistos da cepa ME-49 de T. gondii. A sobrevida foi monitorada até o $30^{\circ}$ dia após a infecção e os resultados foram obtidos com 10 animais em cada grupo experimental. Os animais $\mathrm{CCR} 5^{-/-}$foram significativamente mais suscetíveis à infecção quando comparados aos animais controle $\left(\chi^{2}=14,39 ; \mathrm{P}=0,0001 ; \mathrm{df}=1\right)$. 


\subsection{Parasitismo tecidual dos camundongos $\mathrm{CCR5}^{-/-}$e C57BL/6 infectados}

Para verificar se a mortalidade acentuada dos animais $\mathrm{CCR} 5^{-/-}$pode estar relacionada ao aumento da replicação do parasito nos locais de infecção, camundongos C57BL/6 e $\mathrm{CCR}^{-/-}$foram infectados por via oral com 5 cistos de T. gondii e analisados quanto ao parasitismo tecidual no intestino delgado e no fígado por qPCR. Os resultados demonstraram que, após este período de infecção, houve um aumento significativo de parasitos no intestino delgado (Figura 3A) e no fígado (Figura 3B) de animais $\mathrm{CCR}^{-/-}$quando comparados com os animais controle infectados. Esses resultados demonstram que a ausência de CCR5 compromete o controle da replicação do parasito na fase aguda da infecção.

A

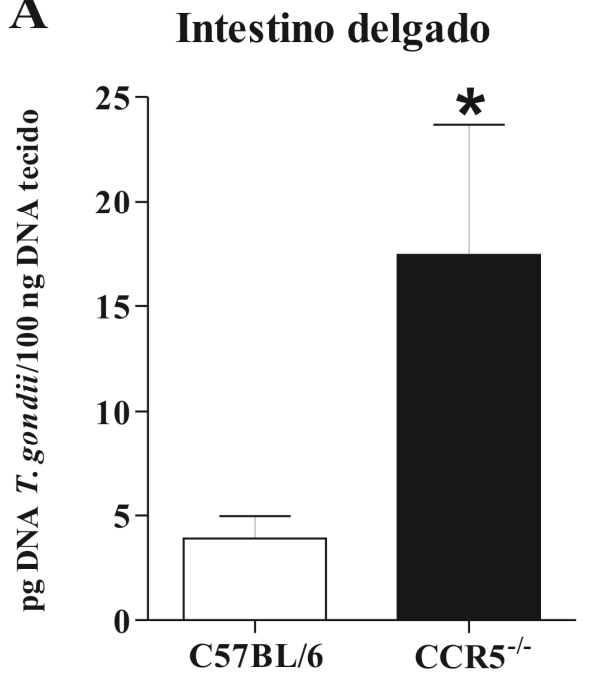

B

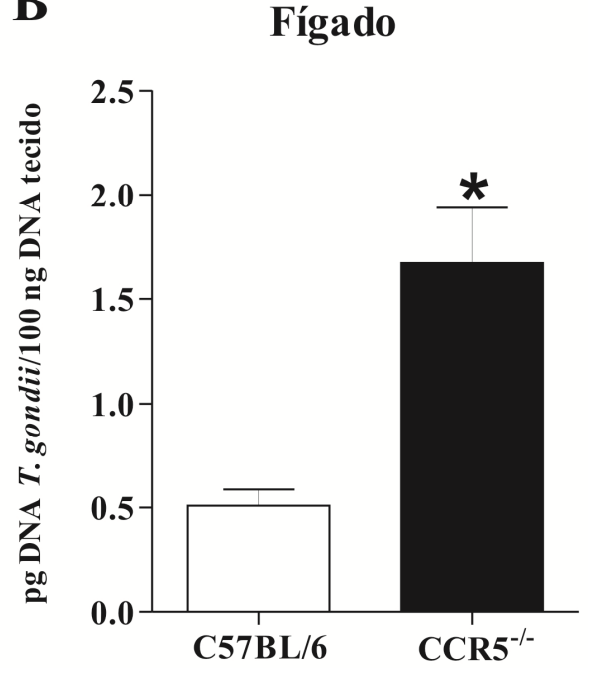

Figura 3. Parasitismo tecidual de camundongos $\mathrm{CCR5}^{-/}$e C57BL/6 infectados com T. gondii. Grupos de camundongos $\mathrm{CCR}^{-1-}$ e C57BL/6 foram infectados por via oral com 5 cistos de $T$. gondii. No $8^{\circ}$ dia após infecção, intestino delgado (A) e fígado (B) foram coletados, o DNA total foi extraído e o parasitismo tecidual foi determinado por PCR em tempo real baseado em uma curva padrão com DNA de T. gondii. Os valores obtidos são apresentados como picograma de DNA do parasito por 100 nanograma de DNA total do tecido analisado. Os resultados foram obtidos com 4 animais por grupo. * indica significativamente diferente de valores obtidos de animais controle infectados $(\mathrm{p}<0,05)$. 


\subsection{Análise histopatológica dos órgãos periféricos após a infecção}

Com o intuito de verificar quais alterações histopatológicas o parasito estava causando nos animais deficientes de CCR5, visto que estes animais apresentaram um maior parasitismo tecidual, fragmentos do cérebro, pulmão, intestino delgado e fígado foram coletados no $8^{\circ}$ dia após infecção com 5 cistos de $T$. gondii. Os tecidos foram então processados, submetidos à coloração com H\&E e analisados.

No período avaliado de infecção, fígado e intestino delgado foram os órgãos que mais apresentaram inflamação em ambos os camundongos, C57BL/6 e CCR5 $5^{-/}$. Os camundongos WT apresentaram um moderado infiltrado inflamatório na lâmina própria (LP), epitélio e submucosa do intestino delgado. Em algumas áreas foi observado um reduzido comprimento e aumentada espessura das vilosidades (Figura 4A). No entanto, camundongos CCR5 $5^{-1-}$ apresentaram um intenso infiltrado inflamatório no intestino delgado, predominantemente no jejuno e no íleo (Figura 4B), no qual foi verificada completa desorganização das vilosidades com focos de necrose (Figura 4B, $\triangleright$ ). Em algumas áreas foram observadas delimitadas regiões de ulceração epitelial.

$\mathrm{O}$ fígado dos animais C57BL/6 e $\mathrm{CCR}^{-/-}$infectados apresentaram lesões caracterizadas por infiltrados inflamatórios organizados como foco no parênquima e em áreas portais, constituídos principalmente por células mononucleares (Figura 4C e D, *). Entretanto, nos camundongos $\mathrm{CCR}^{-/}$foi observada uma extensiva vacuolização dos hepatócitos, que foi sugestiva de acúmulo de lipídios como resultado de uma importante alteração metabólica (4D, $\rightarrow)$. O CNS e o pulmão foram também analisados para alterações histopatológicas no $8^{\circ}$ dia após infecção e apresentaram uma leve alteração inflamatória neste período de infecção (dados não mostrados). Assim, estes resultados demonstram que, mesmo com baixo inóculo, o processo inflamatório causado pela infecção com $T$. gondii é mais elevado no íleo na ausência de CCR5. Não há diferença no infiltrado inflamatório do fígado entre os grupos de animais estudados, porém a deficiência de CCR5 leva a formação de vacúolos, indicadores de acumulo de lipídios. 

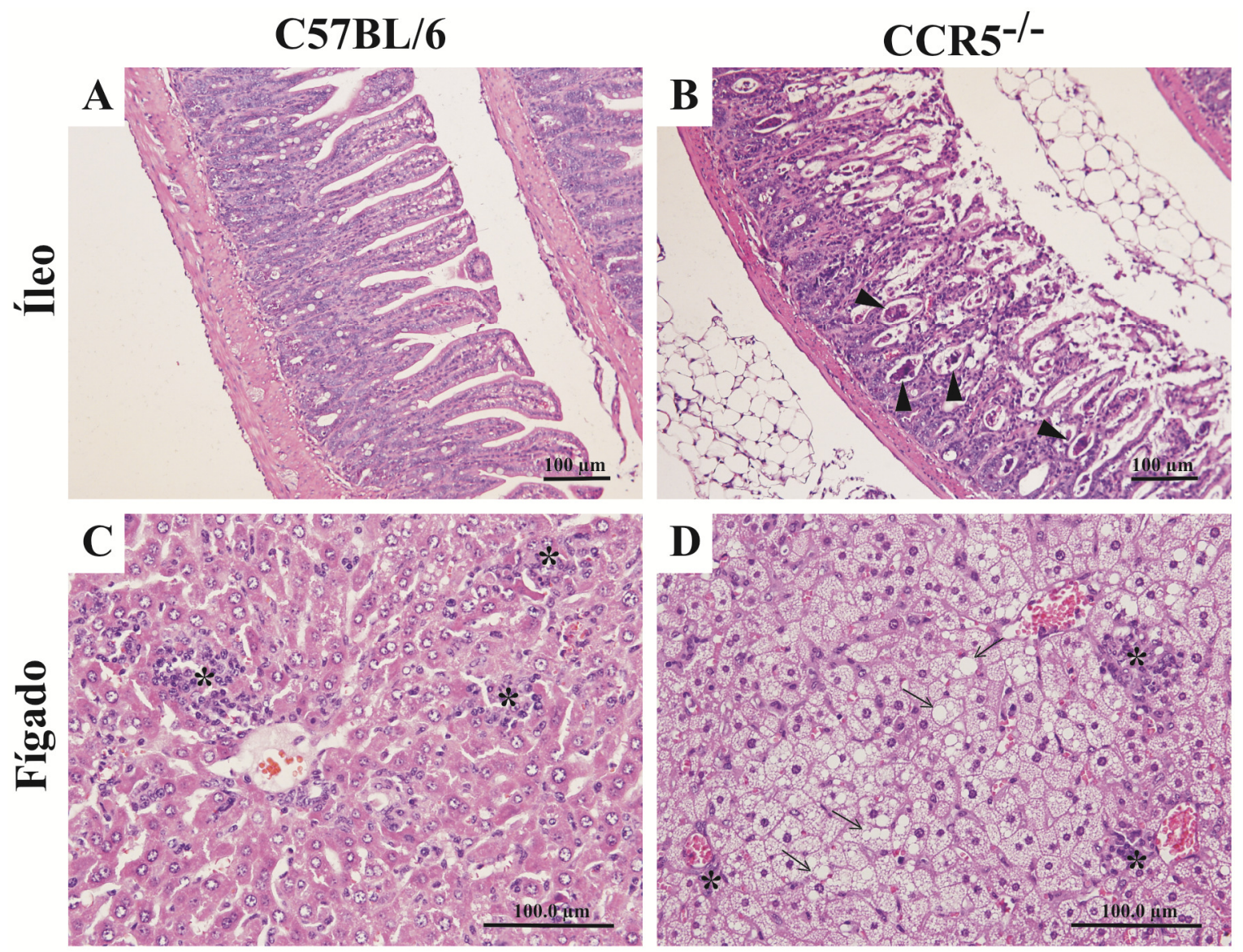

Figura 4. Análise histopatológica do íleo e fígado de camundongos $\mathrm{CCR5}^{-/-}$e C57BL/6 infectados com T. gondii. Grupos de camundongos $\mathrm{CCR}^{-/-}$e C57BL/6 foram infectados por via oral com 5 cistos de $T$. gondii. No $8^{\circ}$ dia após infecção, íleo (A e B) e fígado (C e D) foram coletados, fixados, parafinados e corados por H\&E. Os resultados foram obtidos em 4 animais de cada grupo experimental. *: infiltrado inflamatório; $\rightarrow$ : vacúolos;

\subsection{Infiltrado celular presente no intestino delgado}

O intestino delgado é o primeiro órgão a ser afetado na infecção oral por T. gondii. O parasito desencadeia uma série de mediadores responsáveis pela ativação e recrutamento celular, definindo assim o conjunto de células inflamatórias no local da infecção. O perfil celular presente no intestino delgado de animais infectados com $T$. gondii é muito importante, pois pode conferir uma inflamação exacerbada mediada pela resposta efetora, ou uma moderada regulação suficiente para sobrevivência do parasito no hospedeiro. Para caracterizar tal evento, os leucócitos provenientes da lâmina própria (LP) foram isolados de animais WT e $\mathrm{CCR}^{-/-}$no $8^{\circ}$ dia após a infecção e foram caracterizados quanto aos principais subtipos celulares envolvidos na resposta contra o parasito. Foi possível observar que houve uma 
maior frequência de células $\mathrm{TCD}^{+} \mathrm{CD}^{+}$na LP dos animais $\mathrm{CCR} 5^{-/-}$em comparação com animais controle, porém não houve diferença significativa na freqüência de linfócitos $\mathrm{TCD}^{+} \mathrm{CD}^{+}$(Figura 5A). Dentro da subpopulação de linfócitos $\mathrm{CD} 4^{+}$houve aumento na freqüência de células $\mathrm{CD} 25^{-}$entre os animais $\mathrm{CCR} 5^{-/-}$e não foram observadas diferenças entre as células $\mathrm{CD}_{25^{+}}$na LP (Figura $5 \mathrm{C}$ ) em relação aos animais controle infectados. Dentre os resultados obtidos na análise do infiltrado inflamatório foi possível detectar também uma menor frequência na população de células CD3NK1.1+ (Figura 5B), que caracteriza células $\mathrm{NK}$, e uma menor porcentagem de células $\mathrm{CD} 4^{+} \mathrm{CD} 25^{-}$Foxp $^{+}$(Figura 5D) nos animais deficientes em CCR5 em comparação com animais controle. Esses resultados em conjunto sugerem que CCR5 é importante para migração de alguns subtipos celulares e que em sua ausência pode haver uma compensação celular, com recrutamento envolvendo outros receptores de quimiocinas.

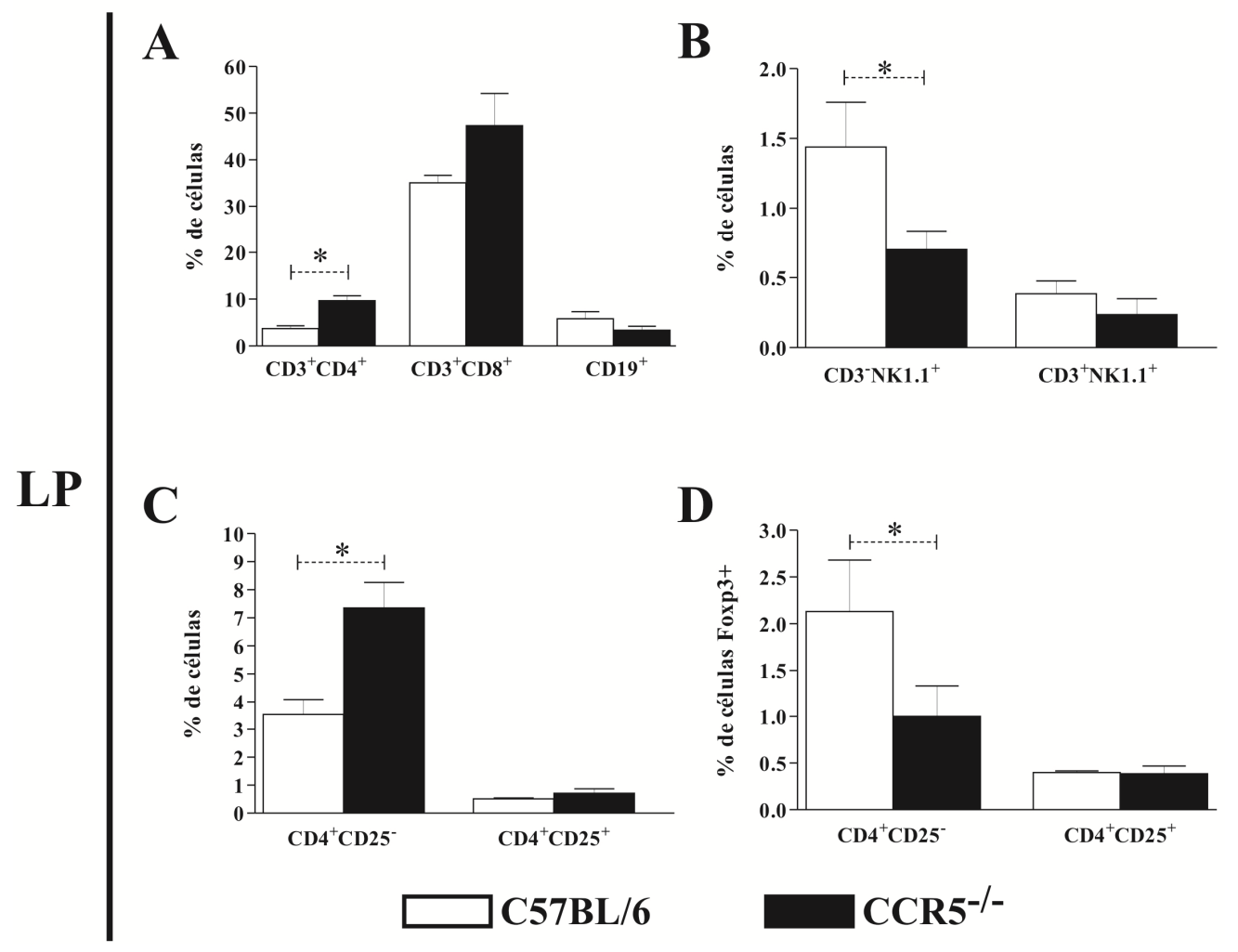

Figura 5. Análise do infiltrado celular na lâmina própria do intestino delgado em camundongos $\mathrm{CCR5}^{-/}$e C57BL/6 infectados com $\mathrm{T}$. gondii. Camundongos $\mathrm{CCR}^{-/}{ }^{-\alpha}$ e C57BL/6 foram infectados por via oral com 5 cistos de $T$. gondii e no $8^{\circ}$ dia após infecção, linfócitos da lâmina própria (LP) (A, B, C e D) foram extraídos do intestino delgado desses animais e caracterizados quanto aos principais subtipos celulares envolvidos na resposta ao parasito. As análises foram obtidas de populações de linfócitos identificadas pelos gráficos de granulosidade e tamanho das células extraídas. Os resultados foram obtidos em 4 animais de cada grupo experimental.* indica $\mathrm{p}<0,05$. 


\subsection{Caracterização macroscópica e marcação de lipídeos no fígado dos camundongos infectados}

Como observado por meio da análise histológica, animais $\mathrm{CCR} 5^{-/-}$infectados com $T$. gondii apresentam um quadro de vacuolização no fígado (Figura 4D) sugestiva de acúmulo de lipídeos. Foi observado também macroscopicamente que o fígado desses animais possuía coloração pálida, diferente da coloração observada em animais sadios. Para verificar se essa vacuolização de fato é causada por acumulo de lipídeos, animais $\mathrm{CCR}^{-{ }^{--}}$e animais WT foram infectados com $T$. gondii e no $8^{\circ}$ dia após a infecção o fígado foi coletado, fotografado, pesado e um fragmento foi congelado em OCT Tissue Tek® e as amostras foram estocadas a $-70^{\circ} \mathrm{C}$ para realização da marcação para lipídeos. Com o auxílio de um criostato, foram obtidos cortes com $5 \mu \mathrm{m}$ de espessura, utilizados para coloração com Sudão III, que marca lipídeos neutros em vermelho vivo e ésteres de colesterol em alaranjado. Os resultados demonstraram que, o fígado dos animais $\mathrm{CCR} 5^{-/-}$, como dito anteriormente, apresentou-se pálido, de maior tamanho e massa, em relação aos animais controle infectados e não infectados (Figura 6A e B). Como observado pela coloração com Sudão III, houve um elevado acúmulo de lipídeos no fígado dos camundongos $\mathrm{CCR}^{-/-}$infectados com T. gondii, identificado por meio da marcação em vermelho (Figura 6F), quando comparados aos animais C57BL/6 infectados (Figura 6E) e não infectados (Figura 6C e D). Esses dados sugerem que a infecção com $T$. gondii na ausência de CCR5 pode causar um extenso quadro de dano hepático com aumento de tamanho e peso do fígado e disfunção metabólica, que leva ao acúmulo de lipídeos neste órgão. 
A

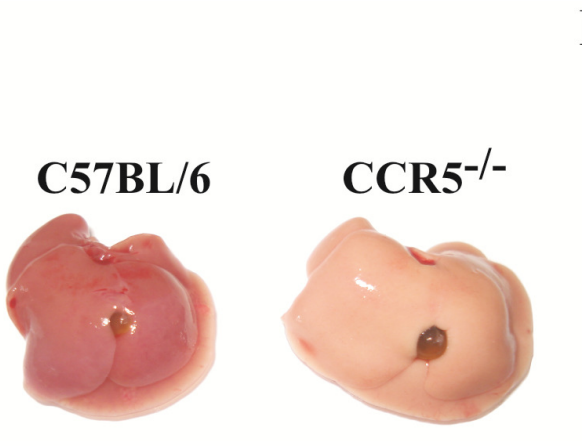

B

C57BL/6
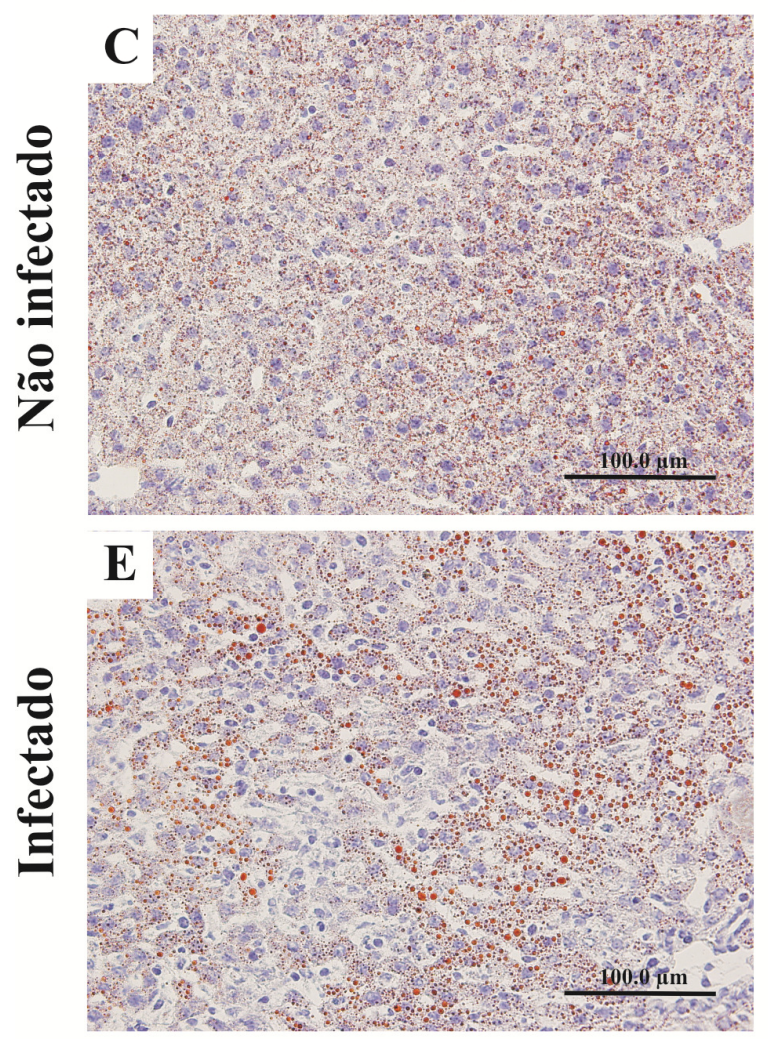

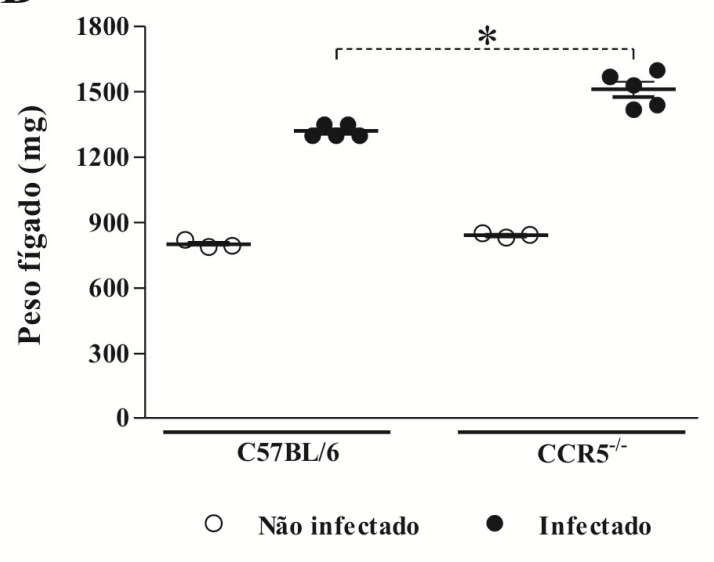

$\mathrm{CCR5}^{-/-}$
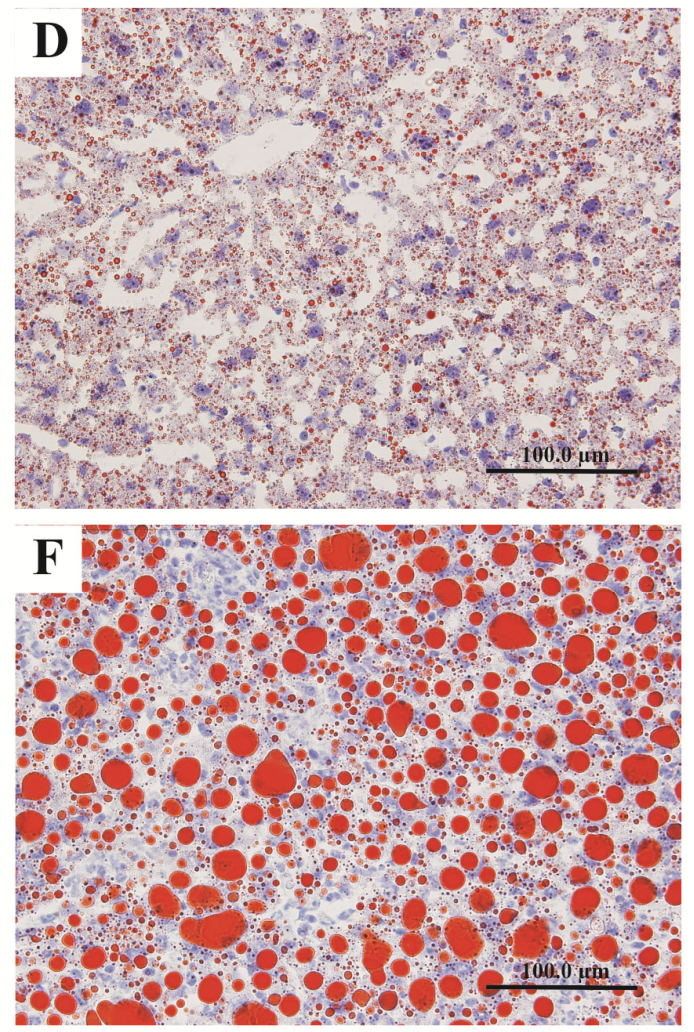

Figura 6. Análise macroscópica e microscópica do fígado por marcação de lipídeos em camundongos $\mathrm{CCR5}^{-/}$e C57BL/6 infectados com T. gondii. Animais CCR5 ${ }^{-1-}$ e C57BL/6 foram infectados por via oral com 5 cistos de T. gondii. No $8^{\circ}$ dia após infecção, o fígado foi coletado, fotografado (A), pesado (B) e congelado em meio OCT. Cortes do tecido congelado foram corados com Sudão III, um corante específico para marcação de lipídeos e ácidos graxos (C, D, E e F). Os resultados foram obtidos em 3-5 animais de cada grupo experimental. * indica $\mathrm{p}<0,05$. 


\subsection{Dosagem de triglicérides e transaminases (ALT e AST) no soro dos camundongos infectados}

Associado aos dados observados anteriormente, no qual houve aumento do fígado e acúmulo de lipídeos nos animais $\mathrm{CCR}^{-/}$infectados com $T$. gondii, observou-se também que o soro desses animais possuia característica lipêmica. Assim, para caracterizar bioquimicamente e confirmar a lesão hepática observada, o soro de animais C57BL/6 e $\mathrm{CCR}^{-/-}$após o $8^{\circ}$ dia de infecção com $T$. gondii foi submetido à dosagem de triglicérides e de enzimas envolvidas no metabolismo hepático, tais como transaminase pirúvica (ALT) transaminase oxalacética (AST).

Após o $8^{\circ}$ dia de infecção, animais $\mathrm{CCR}^{-/-}$infectados apresentaram uma elevada concentração sérica de triglicérides (Figura 7A), quando comparados aos animais controle. Além disso, animais selvagens infectados com T. gondii apresentaram um aumento significativo na concentração de ALT (Figura 7B) quando comparados aos animais não infectados. Porém, quando animais $\mathrm{CCR}^{-/-}$foram infectados, a concentração de AST aumentou significativamente (Figura 7C), enquanto que a concentração de ALT não apresentou diferença significativa (Figura 7B) em comparação com animais controle infectados.

Esses dados em conjunto com as alterações histopatológicas no fígado indicam que na ausência de CCR5 há um extenso quadro de dano hepático, característico de esteatose, induzidos pela infecção com T. gondii. Esta falha hepática pode ser mais um fator a contribuir para a morte dos animais ainda na fase aguda da infecção. 


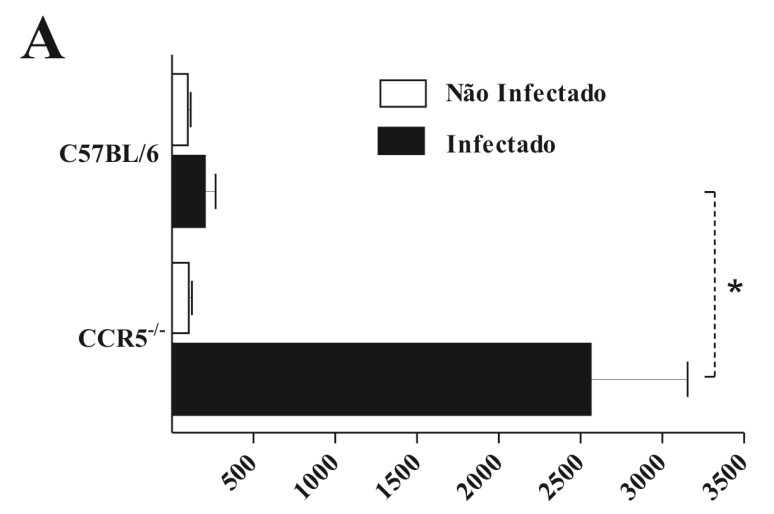

Triglicérides (mg/dL)

B

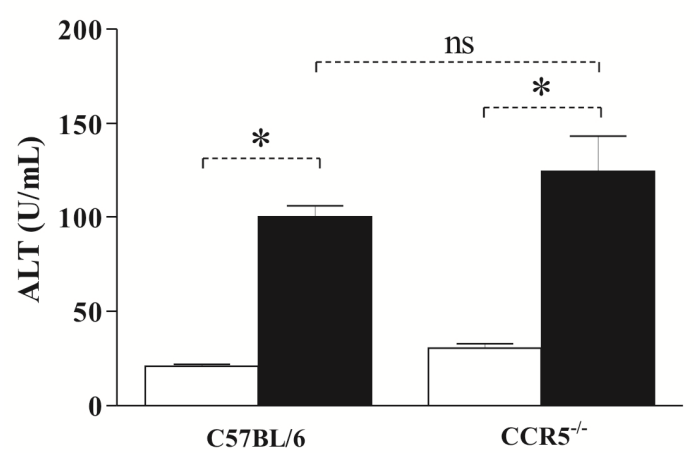

C
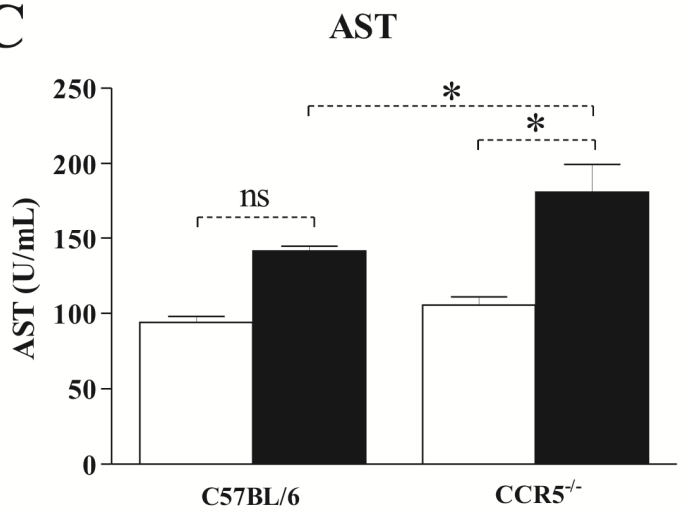

Figura 7. Concentração sérica de triglicérides, ALT e AST em camundongos CCR5 ${ }^{-/}$e C57BL/6 infectados com $\boldsymbol{T}$. gondii. Grupos de camundongos $\mathrm{CCR}^{-/}$e C57BL/6 foram infectados por via oral com 5 cistos de T. gondii. No $8^{\circ}$ dia após infecção, o sangue desses animais foi coletado e processado para obtenção do soro. O soro foi submetido à dosagem de triglicérides totais (A) e de enzimas como transaminase pirúvica (ALT) (B) e transaminase oxalacética (AST) (C) com Kit da Labtest, de acordo com o protocolo fornecido pelo fabricante. Os resultados foram obtidos com 4-5 animais por grupo. * indica $\mathrm{p}<0,05 . \mathrm{ns}=$ não significativo. 


\subsection{Concentração de citocinas pró e anti-inflamatórias nos camundongos infectados}

Devido ao fato dos animais $\mathrm{CCR}^{-/-}$serem mais suscetíveis à infecção por $T$. gondii e apresentarem certo grau de dano hepático, foi avaliado se a ausência de CCR5 afetaria a produção de citocinas. Para quantificar o perfil de citocinas nesses animais, soro e macerado do fígado e íleo de camundongos C57BL/6 e $\mathrm{CCR}^{-/-}$infectados com T. gondii foram submetidos à quantificação de citocinas de perfil pró (IL-12p40, IFN- $\gamma$ e TNF- $\alpha$ ) e antiinflamatório (TGF- $\beta$ e IL-10) por ELISA. Os resultados demonstraram que, após o $8^{\circ}$ dia de infecção, houve um decréssimo significativo na concentração de citocinas pró-inflamatórias IL-12p40, IFN- $\gamma$ (Figura 8A e B) no fígado dos animais CCR5 ${ }^{-/-}$quando comparados com o C57BL/6 infectados. Neste resultado, também é possível observar que as concentrações basais (não infectado) de TNF- $\alpha$, IL-12p40 e IFN- $\gamma$ nos animais $\mathrm{CCR}^{-/-}$já é reduzido, o que pode estar levando a dificuldade de montar uma resposta efetiva (Figura 8A, B e D). Houve também um decrécimo em TGF- $\beta$ nos animais $C C R 5^{-/}$, porém a concentração de IL-10 não se alterou quando comparados aos animais C57BL/6 (Figura 8D e E).

Quando a concentração de citocinas foi avaliada no íleo, foi observado que não houve um decréssimo significativo de citocinas próinflamatórias IL-12p40 e IFN- $\gamma$ (Figura 9A e B) nos animais $\mathrm{CCR}^{-/-}$quando comparados com o C57BL/6 infectados. Para as demais citocinas anti-inflamatórias (TNF- $\alpha$, TGF- $\beta$ e IL-10, Figura 9C-E, respectivamente) também não houve diferença significativa entre os grupos estudados.

Quando a concentração de citocinas foi avaliada no soro, foi observado que não houve diferença significativa em nenhuma das citocinas analisadas entre os grupos infectados estudados (Figura 10A-E).

Esses resultados em conjunto sugerem que, na ausência de CCR5, a resposta inflamatória mediada pela infecção com $T$. gondii envolve um menor controle do parasitismo por meio de uma deficiência na resposta efetora, com diminuída produção de IL-12p40 e IFN- $\gamma$ e uma desbalanço na resposta reguladora devido à reduzida produção de TGF- $\beta$ e igual produção de TNF- $\alpha$ no fígado dos animais $\mathrm{CCR}^{-/-}$. 
A

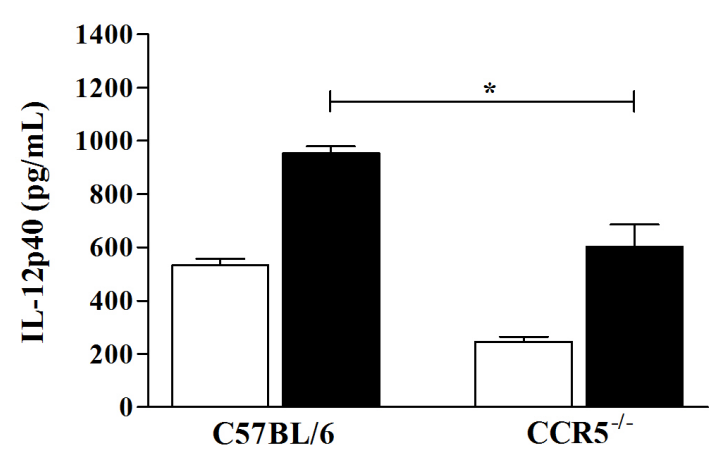

C

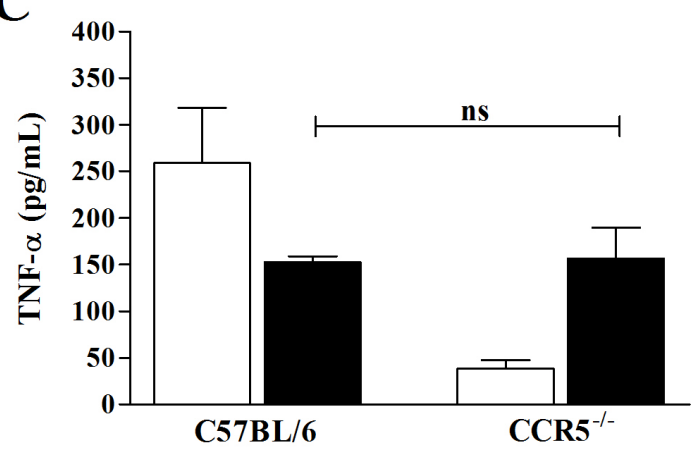

$\mathbf{E}$

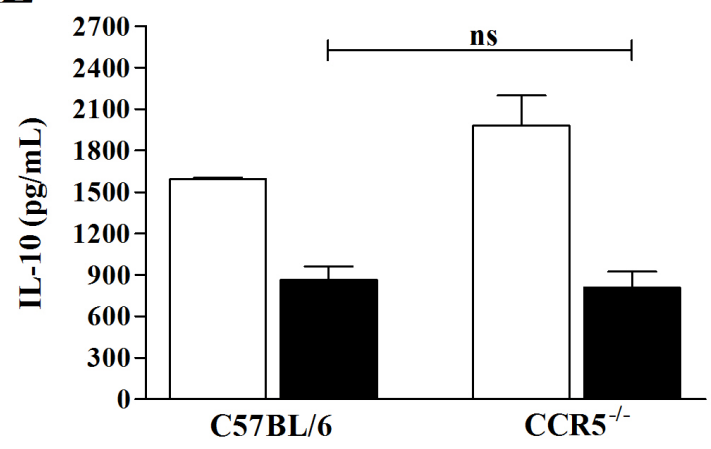

B

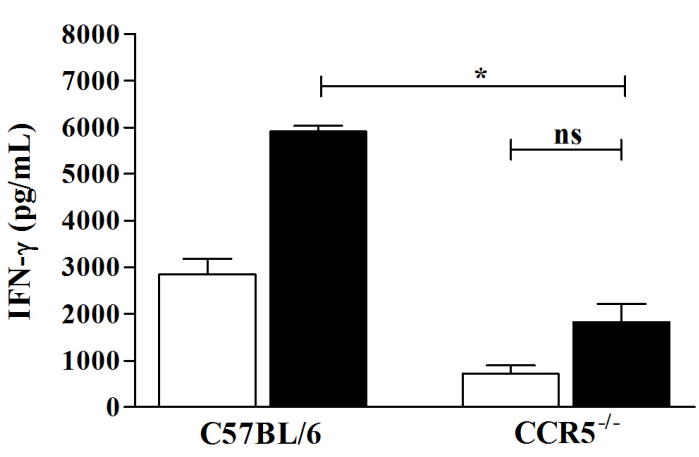

D

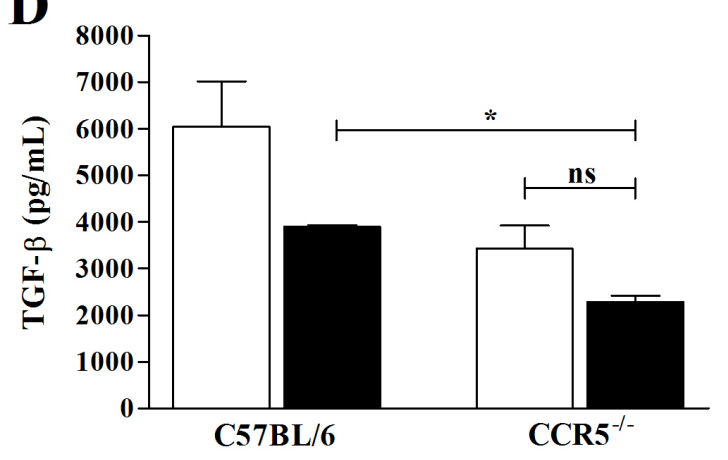

Figura 8. Concentração de citocinas no fígado de animais $\mathrm{C} 57 \mathrm{BL} / 6$ e $\mathrm{CCR5}^{-/}$infectados com $T$. gondii. As concentrações das citocinas IL-12p40 (A), IFN- $\gamma$ (B), TNF- $\alpha$ (C), TGF- $\beta$ (D) e IL-10 (E) foram quantificadas no macerado tecidual do fígado $(100 \mathrm{mg})$ de camundongos C57BL/6 e CCR $5^{-/}$infectados por via oral com 5 cistos de $T$. gondii no $8^{\circ}$ dia após a infecção, utilizando-se o método ELISA. Os resultados foram obtidos com 3-5 animais por grupo experimental. * indica $\mathrm{p}<0,05$. ns = não significativo. 
A

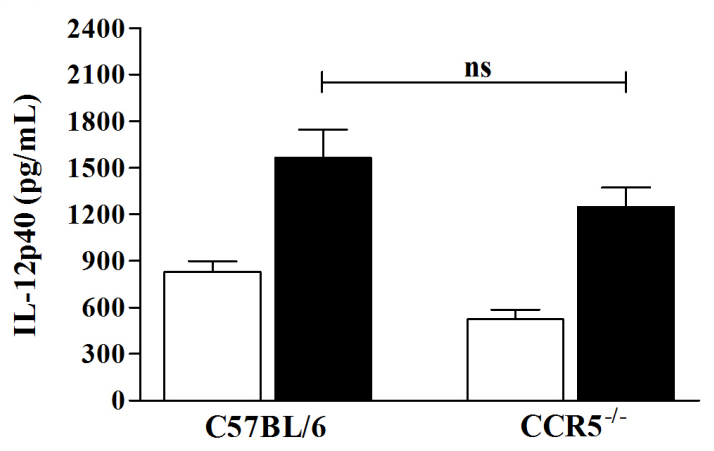

C

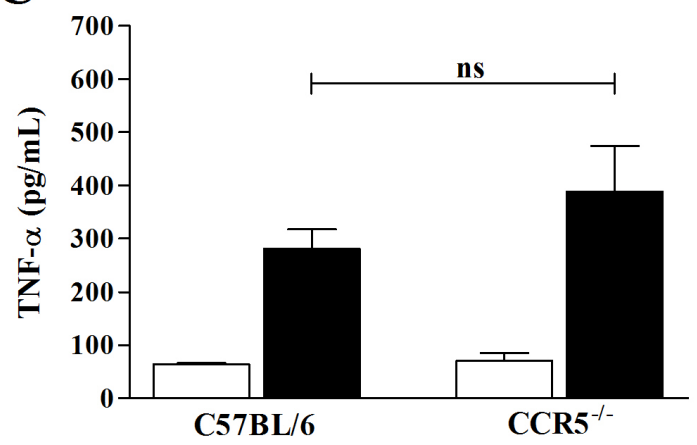

$\mathbf{E}$

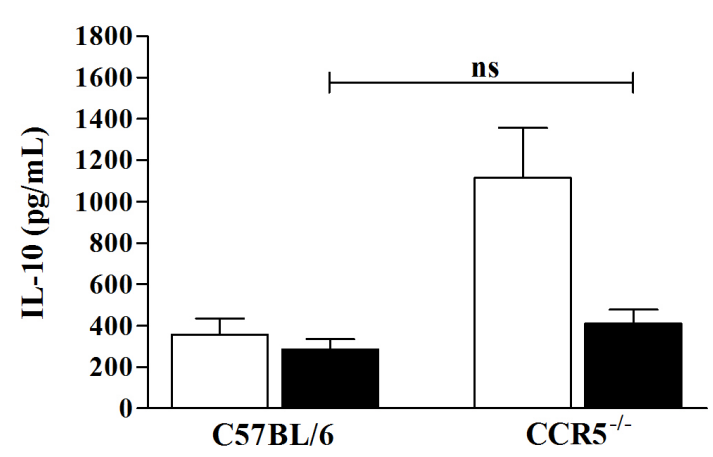

B

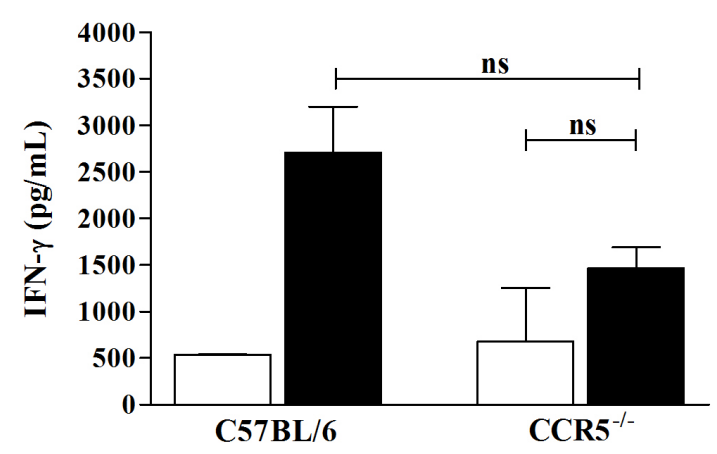

D

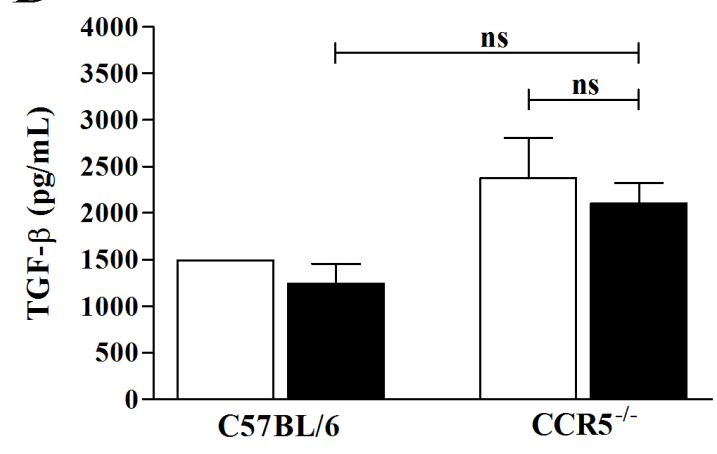

Figura 9. Concentração de citocinas no íleo de animais C57BL/6 e CCR5 ${ }^{-/}$infectados com $T$. gondii. As concentrações das citocinas IL-12p40 (A), IFN- $\gamma$ (B), TNF- $\alpha$ (C), TGF- $\beta$ (D) e IL-10 (E) foram quantificadas no macerado tecidual do íleo $(100 \mathrm{mg})$ de camundongos C57BL/6 e CCR5 $5^{-/}$infectados por via oral com 5 cistos de $T$. gondii no $8^{\circ}$ dia de infecção, utilizando-se o método ELISA. Os resultados foram obtidos com 3-5 animais por grupo experimental. * indica $\mathrm{p}<0,05$. ns = não significativo. 
A

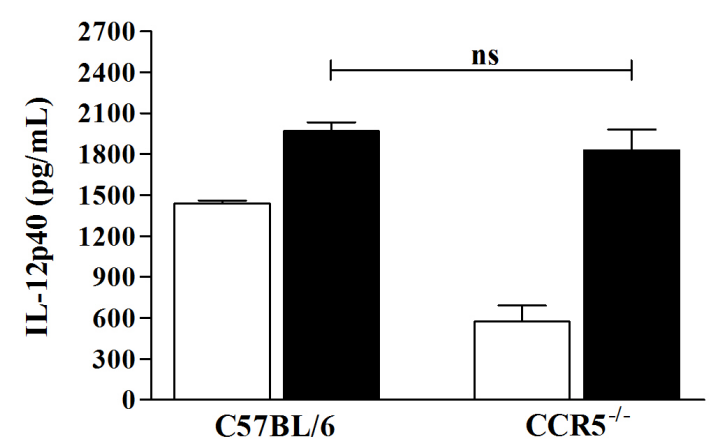

C

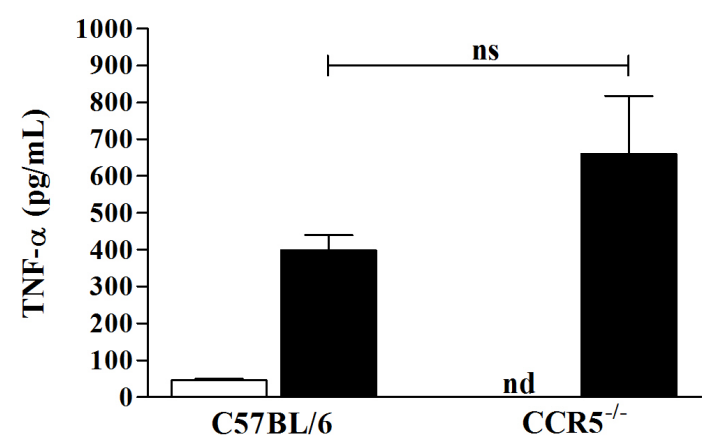

$\mathbf{E}$

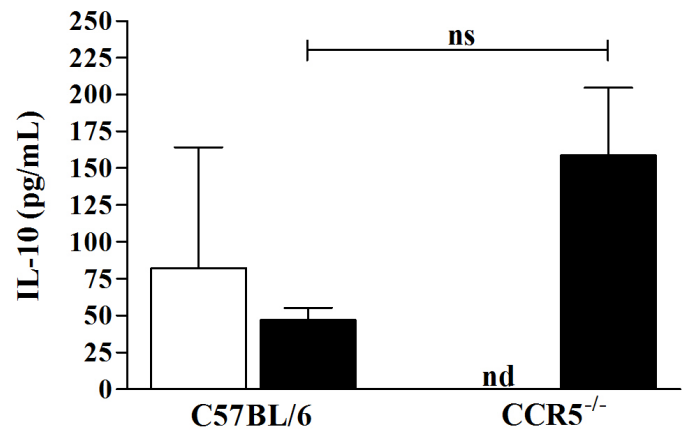

B

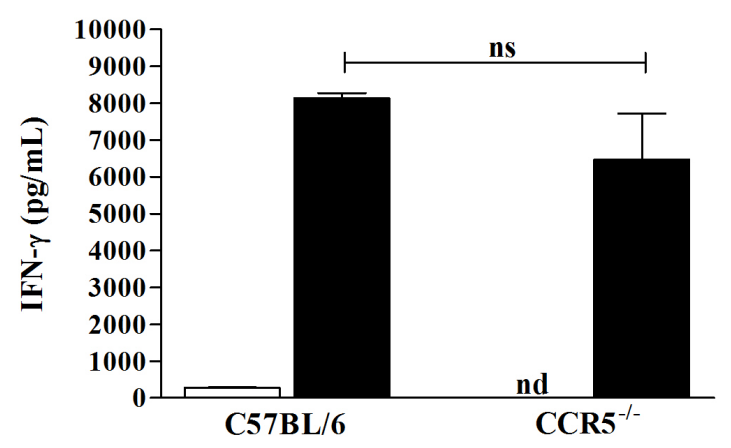

D

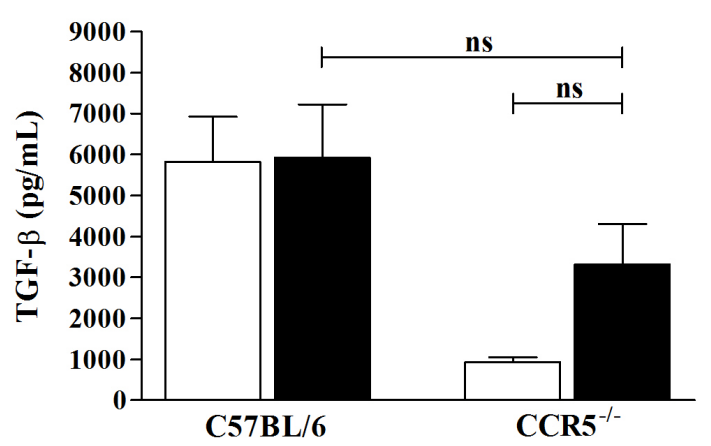

Figura 10. Concentração de citocinas no soro de animais C57BL/6 e CCR5 ${ }^{-/}$infectados com $T$. gondii. As concentrações das citocinas IL-12p40 (A), IFN- $\gamma$ (B), TNF- $\alpha$ (C), TGF- $\beta$ (D) e IL-10 (E) foram quantificadas no soro de camundongos C57BL/6 e CCR $5^{-/}$infectados por via oral com 5 cistos de $T$. gondii no $8^{\circ}$ dia de infecção, utilizando-se o método ELISA. Os resultados foram obtidos com 3-5 animais por grupo experimental. $*$ indica $\mathrm{p}<0,05 . \mathrm{ns}=$ não significativo. $\mathrm{nd}=$ não determinado. 


\subsection{Expressão de RNA mensageiro nos camundongos infectados $\operatorname{com} T$. gondii}

Assim que foi determinado um extenso quadro de acúmulo de lipídeos no fígado dos animais deficientes de CCR5, tornou-se essencial determinar quais fatores estavam causando esta alteração metabólica. Com o intuito de determinar a indução de alguns genes chaves durante a infecção por T. gondii, animais $\mathrm{CCR}^{-1-}$ e WT foram infectados por via oral e no $8^{\circ}$ dia após a infecção foram coletados fragmento do fígado e íleo para purificação e análise do RNA mensageiro quanto a transcrição de alguns genes por PCR em tempo real. Os resultados revelaram que houve uma diminuida indução das quimiocinas CCL3 e CCL4 nos animais $\mathrm{CCR}^{-/-}$, porém não houve diferença significa na expressão de CCL5 no fígado desses animais quando comparados aos animais controle infectados (Figura 11A). Foi observado também uma diminuida indução da expressão da subunidade p40 de IL-12 nos animais deficientes de CCR5, chegando ao mesmo estado dos animais não infectados (Figura 11B). Houve uma menor expressão de IL-17 no íleo dos animais $\mathrm{CCR} 5^{-/-}$e não houve diferença significativa no fígado entre os animais estudados (Figura 11B).

Dentre os mecanismos efetores importantes para o controle do parasitismo podemos destacar a expressão da enzima óxido nítrico sintase induzível (iNOS), cujo produto de sua ação, o óxido nítrico (NO), pode tanto controlar a replicação do parasito ou induzir uma inflamação exacerbada. Foi observado neste trabalho que houve indução de iNOS no fígado dos animais $\mathrm{CCR}^{-/-}$, porém essa indução foi menor em relação aos animais C57BL/6 infectados (Figura 11B). Diferente do observado no fígado, o íleo dos animais CCR5 $5^{-/-}$ infectados apresentou uma reduzida expressão de iNOS em comparação com animais não infectados, enquanto que nos animais controle WT houve indução desta molécula após infecção (Figura 11B).

Com relação aos fatores de transcrição, Foxp3 foi induzido no fígado em até duas vezes no $8^{\circ}$ dia após infecção em animais WT, porém sua indução foi reduzida a expressão normal nos animais deficientes de CCR5 (Figura 11C). Apesar de ROR- $\gamma$ t ter sua indução reduzida em ambos animais experimentais quando infectados, não houve diferença significativa entre ele (Figura 11C). Foi possível observar que, no $8^{\circ}$ dia após infecção com $T$. gondii, o fígado dos animais $\mathrm{CCR}^{-/-}$possuiu uma maior indução na expressão de PPAR $\gamma$ enquanto que PPAR $\alpha$ foi menos expresso quando comparados aos animais controle infectados. Com esses resultados é possível sugerir que, na ausência de CCR5, os animais não conseguem controlar a infecção do parasito, devido a uma diminuida regulação, levando a alteração na expressão de genes envolvidos no metabolismo de lipídeos e consequentemente ao quadro inflamatório de toxicidade hepática. 
A

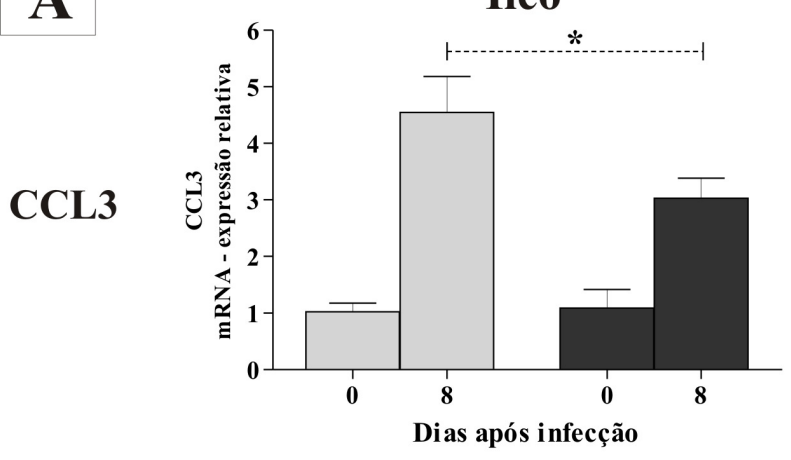

CCL4

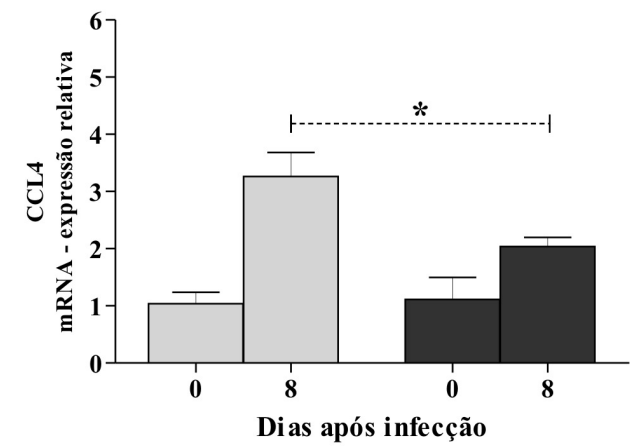

CCL5

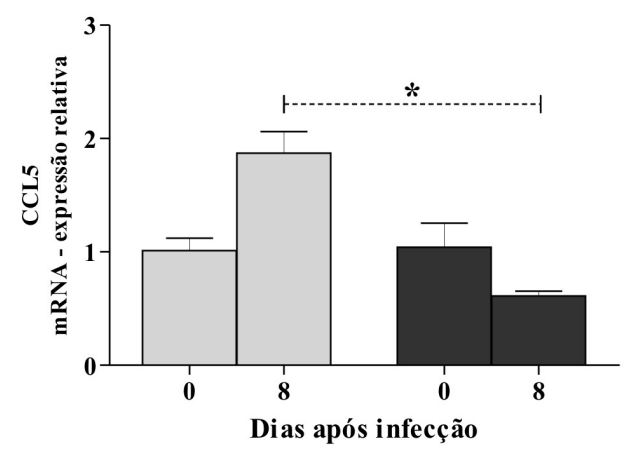

Fígado
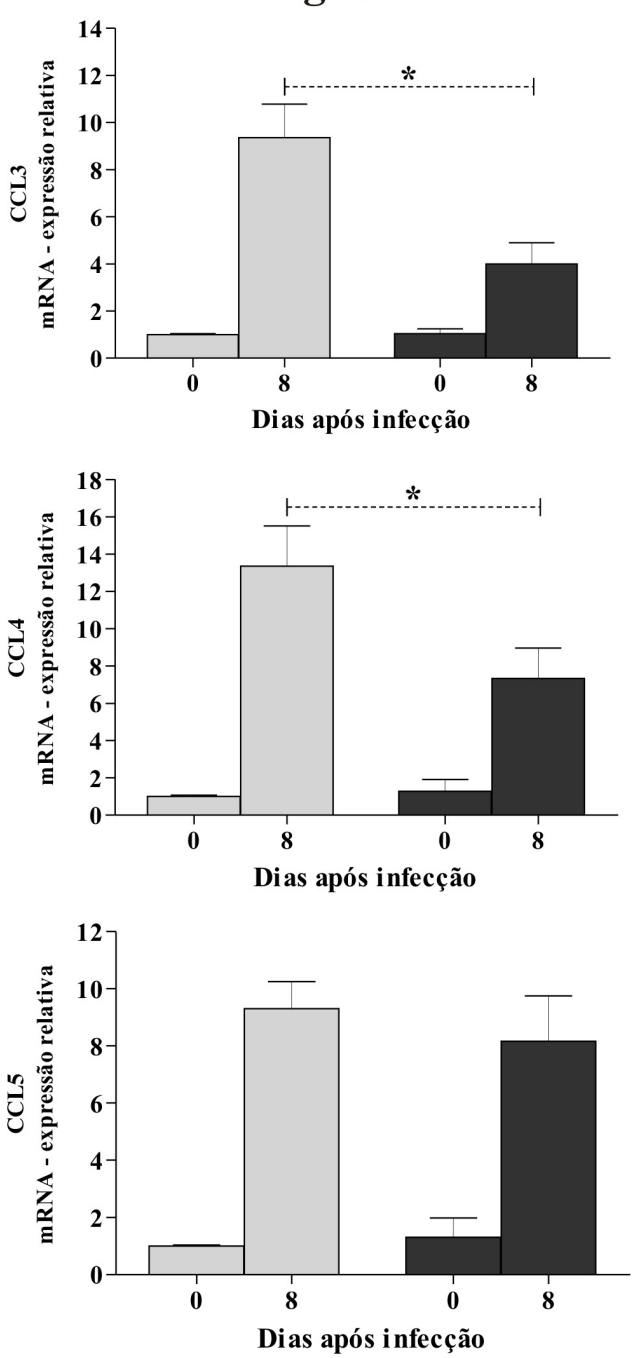

$\mathrm{CCR5}^{-1-}$

Figura 11. Expressão de alguns genes envolvidos na resposta imune no fígado e íleo de camundongos C57BL/6 e CCR5 ${ }^{-/}$infectados com T. gondii. Animais C57BL/6 e CCR5 deficientes foram infectados com 5 cistos de $T$. gondii e no $8^{\circ}$ dia de infecção, fragmentos do fígado e do íleo foram acondicionados e seu RNA extraído. Os transcritos de RNA mensageiro para as quimiocinas CCL3, CCL4 e CCL5 (A), para citocinas IL-12p40, IL-17 e enzimas iNOS (B) e fatores de transcrição Foxp3, PPAR $\alpha$, PPAR $\gamma$ e ROR- $\gamma t$ (C) foram determinadas por PCR em tempo real. Os dados foram normalizados para GAPDH e os valores de $\mathrm{Ct}$ foram analisados pela fórmula $2^{-\Delta \Delta \mathrm{Ct}}$, como demonstrado em material e métodos. $\mathrm{O}$ valor 1 foi adotado como referencial, onde acima indica indução e abaixo indica repressão do gene. Os resultados foram obtidos com 5 animais por grupo experimental. * $\mathrm{p}$ indica $<0,05$. 
B
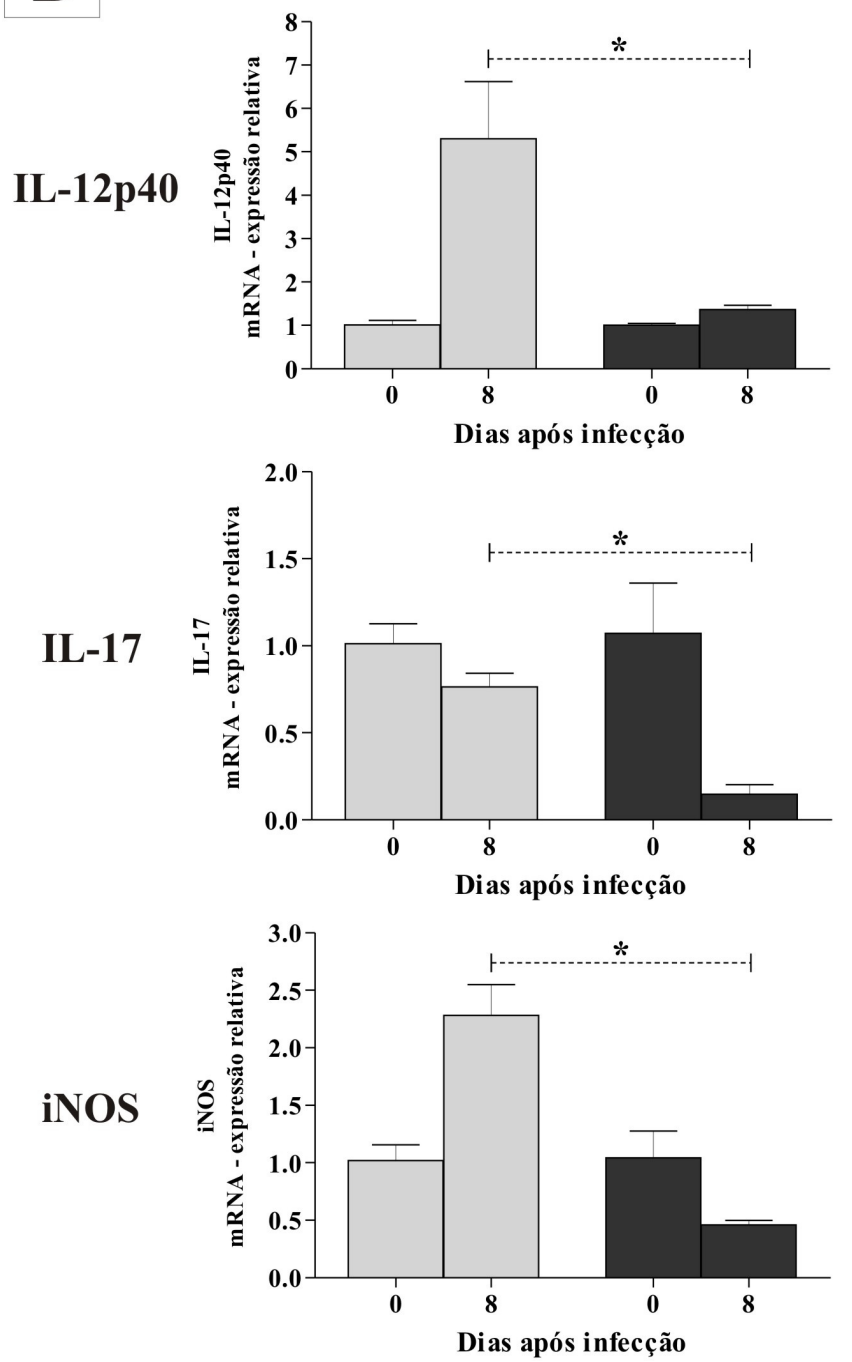

Fígado
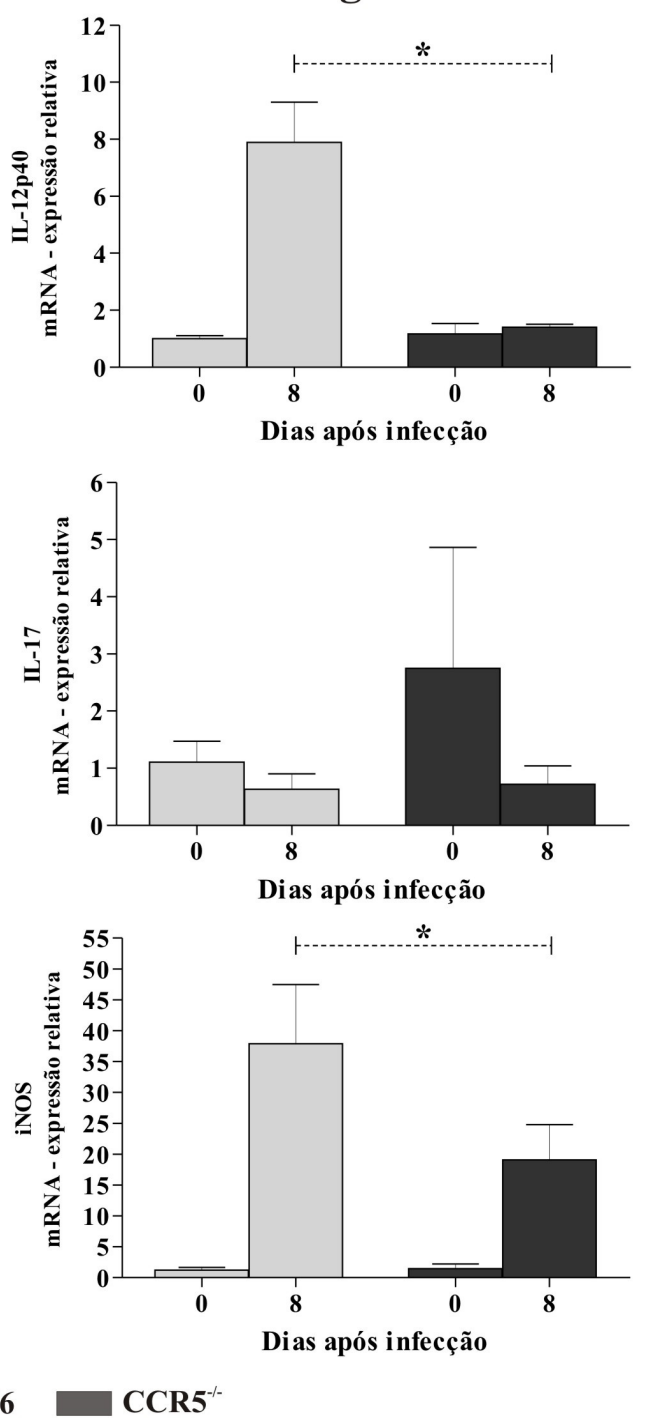

Figura 11. Expressão de alguns genes envolvidos na resposta imune no fígado e íleo de camundongos C57BL/6 e CCR5 ${ }^{-/}$infectados com T. gondii. (Continuação) 
C
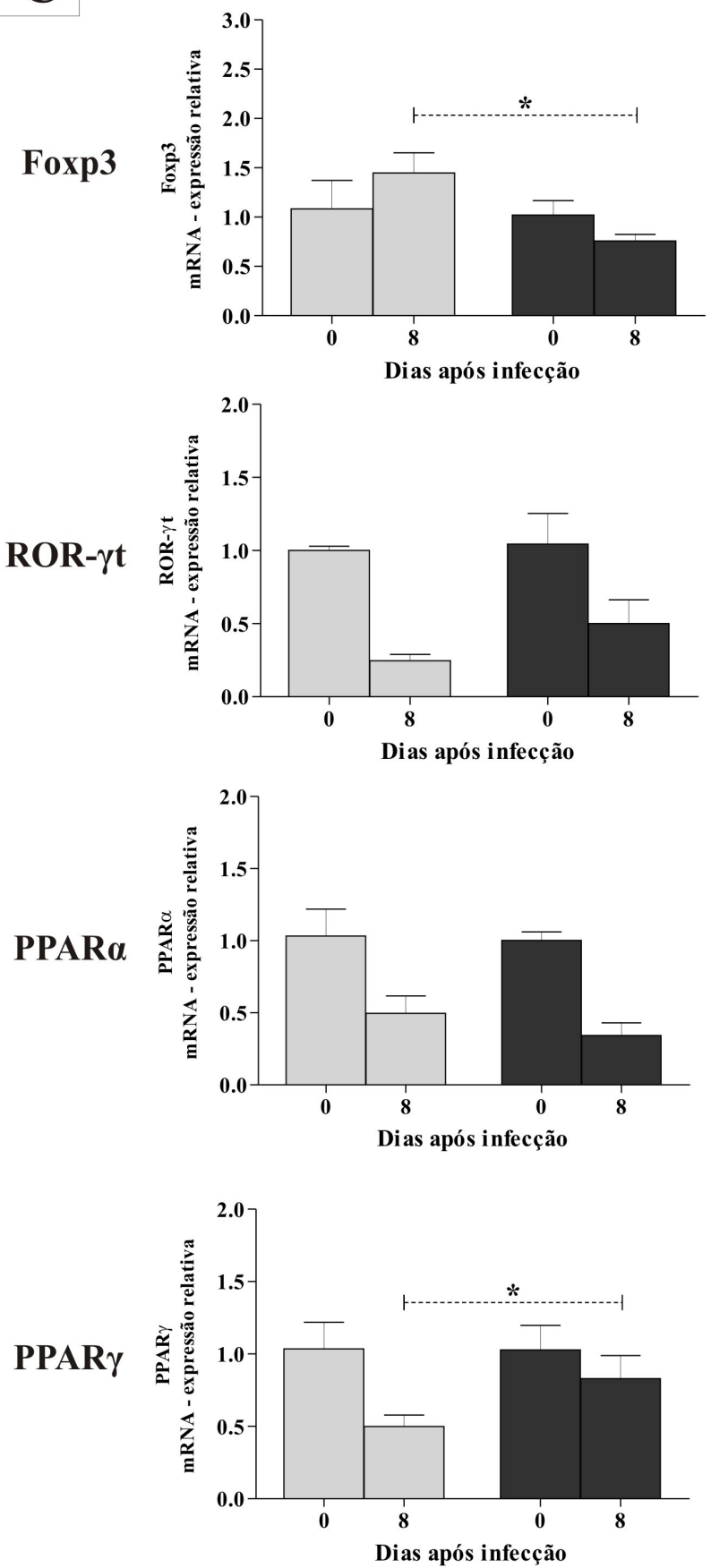

Fígado
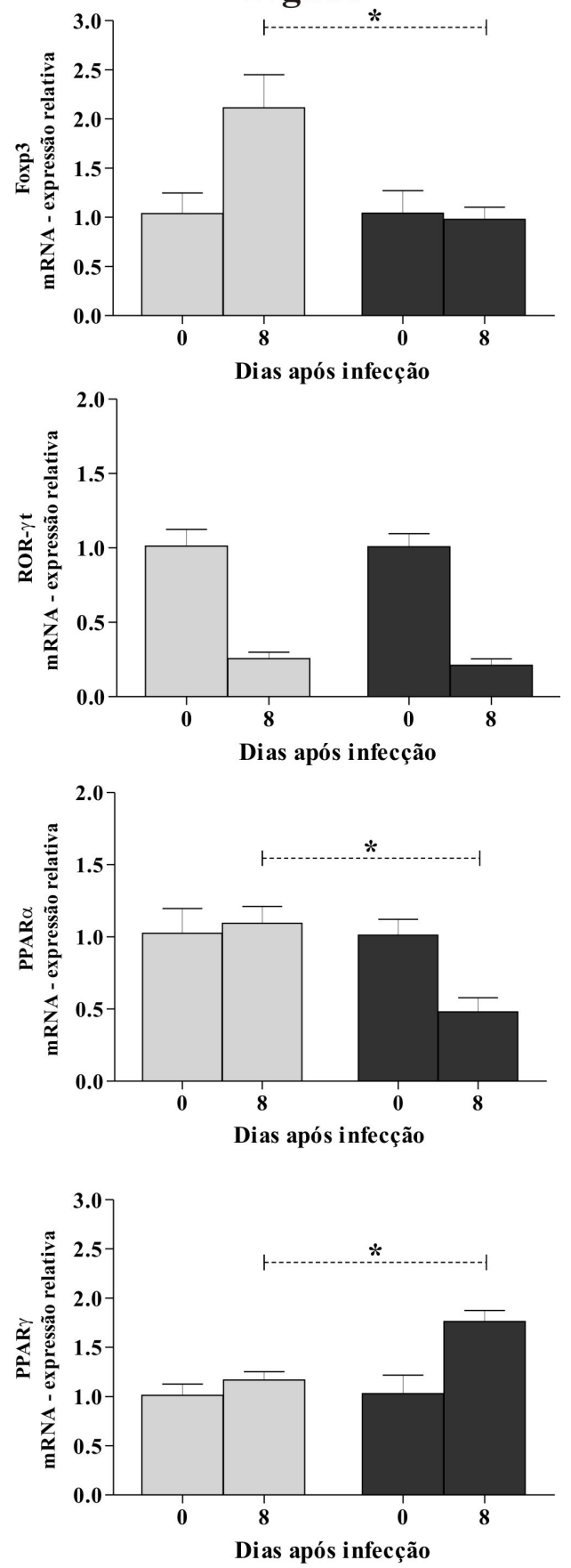

$\mathrm{CCR5}^{-1}$

Figura 11. Expressão de alguns genes envolvidos na resposta imune no fígado e íleo de camundongos C57BL/6 e CCR5 ${ }^{-/}$infectados com T. gondii. (Continuação) 


\subsection{Tratamento dos camundongos com agonista de PPAR $\alpha$ - Gemfibrozil}

Para tentar reverter o quadro de toxicidade hepática e acúmulo de lipídeos no fígado, bem com reduzir a concentração sérica de triglicérides os animais C57BL/6 e CCR5 ${ }^{-1-}$ infectados com $T$. gondii foram tratados com fármaco agonista de PPAR $\alpha$, Gemfibrozil, bem conhecido por sua capacidade de se ligar a PPAR $\alpha$ e reduzir a concentração sérica de triglicérides. Assim, foi observado que 50\% dos animais deficientes em CCR5 infectados com o parasito e tratados com a droga apresentaram reduzida vacuolização, proveniente do acumulo de lipídeos, quando comparados aos animais infectados que receberam apenas veículo (Figura 12D). Não houve alteração quanto ao infiltrado inflamatório desses animais. Houve também uma significativa redução na concentração sérica de triglicérides nesses animais (Figura 12E). Esses dados sugerem que o dano hepático, o quadro de esteatose hepática e a elevada concentração sérica de triglicérides, causados pela infecção com $T$. gondii na ausência de CCR5, estão relacionados com a difunção metabólica provenientes da regulação negativa de PPAR $\alpha$, pois quando há ativação dessa molécula com agonista, há reversão da esteatose observada e redução da concentração de triglicérides no soro. 

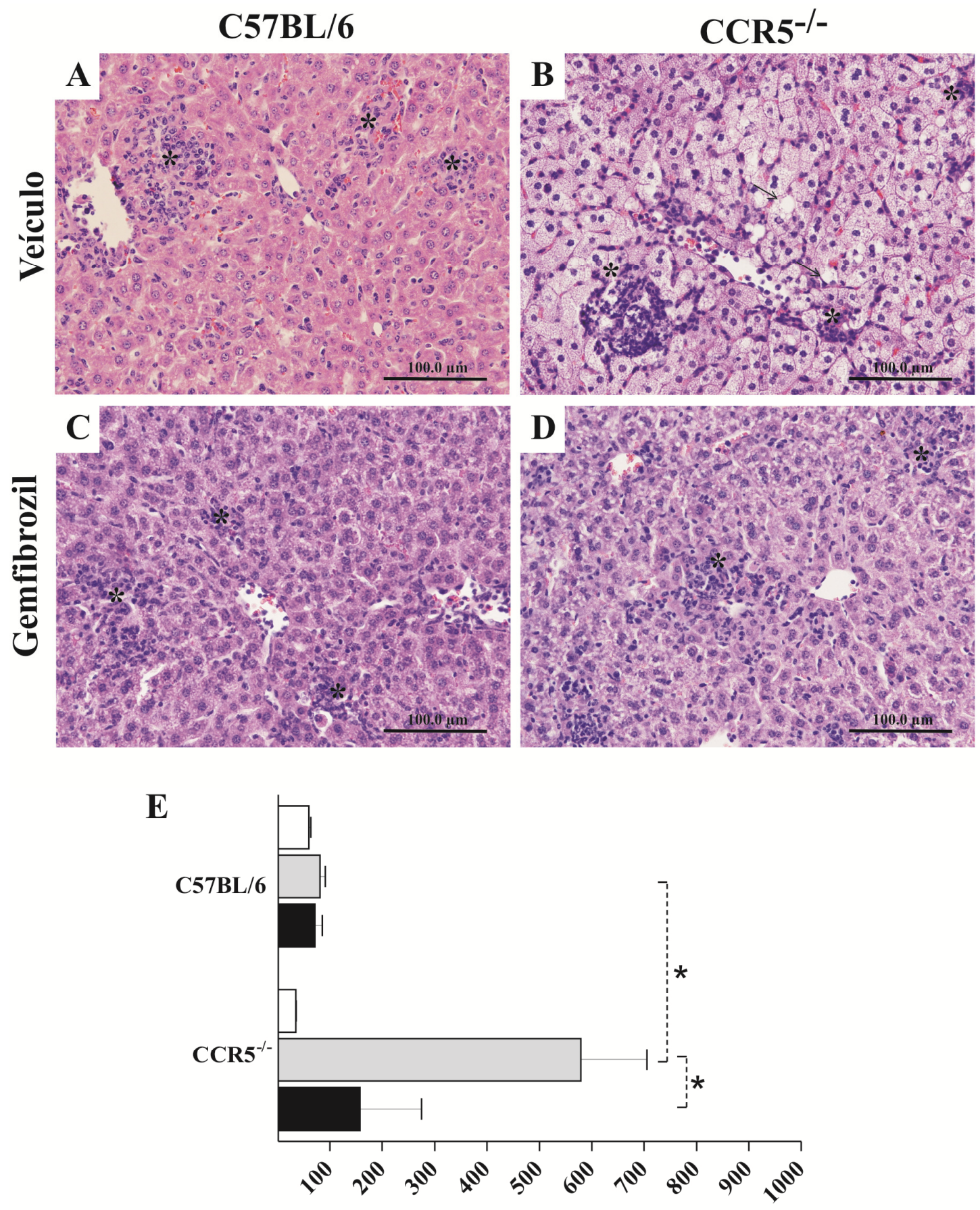

\section{Triglicérides $(\mathrm{mg} / \mathrm{dL})$}

\section{Não Infectado}

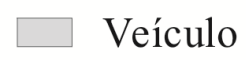

Gemfibrozil

Figura 12. Análise histopatológica do fígado e concentração de triglicérides no soro de camundongos $\mathrm{CCR5}^{-/}$e C57BL/6 infectados com $T$. gondii e tratados com agonista de PPARa (Gemfibrozil). Grupos de camundongos $\mathrm{CCR} 5^{-/}$e C57BL/6 foram infectados por via oral com 5 cistos de $T$. gondii e tratados com Gemfibrozil $100 \mathrm{mg} / \mathrm{Kg} / \mathrm{dia}$, durante 7 dias. No $8^{\circ}$ dia após infecção e tratamento, o fígado (A-D) foi coletado, fixado, parafinado e corado por H\&E. O soro dos animais também foi coletado para dosagem de triglicérides (E). Os resultados foram obtidos em 4 animais de cada grupo experimental. *: infiltrado inflamatório; $\rightarrow$ : vacúolos. $\mathrm{E} *$ indica $\mathrm{p}<0,05$. 
5 - DISCUSSÃO 


\section{DICUSSÃO}

A toxoplasmose é uma doença amplamente distribuída pelo mundo cujo parasito causador, Toxoplasma gondii, pode ser encontrado em diferentes espécies de mamíferos e aves (MONTOYA; LIESENFELD, 2004). Esta doença, que é aparentemente assintomática, pode causar diversas complicações em hospedeiros imunodeficientes, no feto durante a gestação e em determinadas linhagens de modelos experimentais de infecção.

Após a infecção oral por T. gondii, IECs são invadidas pelo parasito, podendo ocorrer distúrbios fisiológicos e morfológicos. Essas células passam a secretar moléculas citotóxicas como NO, além de responderem à infecção pela secreção de várias quimiocinas (CCL2, CXCL2, CCL3 e CCL4) e citocinas (IL-1, IL-6, IL-15, GM-CSF). Tais moléculas são essenciais para o início da resposta imunológica contra o parasito, que culmina em um robusto processo inflamatório no intestino por meio do recrutamento de vários tipos celulares do sistema imunológico, como células $\mathrm{T}$, neutrófilos, macrófagos e células dendríticas (MENNECHET; KASPER et al., 2002; BUZONI-GATEL; SCHULTHESS et al., 2006).

Alguns dos receptores para tais quimiocinas também são ativados durante a infecção com T. gondii. Neste trabalho observamos que, nos tecidos alvo de uma infecção aguda pelo parasito (como íleo e fígado), há indução da expressão de CCR5, bem como da principal quimiocina ligante desse receptor, CCL4, como evidenciado pela formação de transcritos de RNA mensageiro. Essa indução foi mais evidenciada no fígado em comparação com o íleo e isto pode indicar a acentuada importância dessa interação quimiocina-receptor no tecido hepático. CCR5 é caracterizado como um receptor de quimiocina expresso por células residentes ou que migram para o tecido após estimulação por citocinas pró-inflamatórias (IL12, IFN- $\gamma$ e TNF- $\alpha$ ), mediante contato com microrganismos patogênicos (MOSER; LOETSCHER, 2001). Este receptor é principalmente expresso em células T não ativadas, de memória e efetoras, em monócitos, macrófagos e células dendríticas imaturas (SCHALL, 1991; SALLUSTO; LENIG et al., 1999; APPAY; ROWLAND-JONES, 2001) e está intimamente ligado ao recrutamento dessas células para os locais de infecção e inflamação. Com os resultados de expressão gênica de CCR5 e CCL4 observados, é possível sugerir que há um maior recrutamento de células $\mathrm{CCR}^{+}$para os órgãos-alvo iniciais da infecção ou que células residentes são induzidas a expressar mais moléculas desse receptor nos tecidos mencionados estimulados pela infecção com T. gondii. Como já demonstrado, a infecção com este parasito pode levar ao recrutamento de células NK para o baço e fígado e de células $\mathrm{T}$ 
$\mathrm{CD} 8 \alpha^{+}$para o intestino via CCR5, evidenciando sua importância em tal evento (LUANGSAY; KASPER et al., 2003; KHAN et al., 2006).

A resposta imunológica ativada pela infecção com $T$. gondii pode ser influenciada por uma variedade de fatores, incluindo o "background" genético e o sexo do camundongo, a dose e a cepa do parasito (JOHNSON, 1984; LIESENFELD; KOSEK et al., 1996). A infecção oral com 100 cistos de T. gondii, cepa ME-49, leva a morte de 100\% dos camundongos C57BL/6, enquanto que todos os camundongos BALB/c sobrevivem a esta carga parasitária alta. Essa mortalidade elevada é caracterizada pela observação de necrose das vilosidades em células da mucosa intestinal no íleo, a qual não é observada em animais BALB/c no sétimo dia após infecção (LIESENFELD; KOSEK et al., 1996).

Neste trabalho foi utilizado um inoculo de cinco cistos, no qual foi possível avaliar alguns parâmetros de resposta imune e comparar com os animais deficientes de CCR5. Com este inoculo não houve grandes danos aos animais C57BL/6 no $8^{\circ}$ dia após infecção, devido a uma diminuída resposta inflamatória intestinal, que reduz a letalidade nesta linhagem, no qual apenas 25-30\% dos animais sucumbem à infecção em um período de 30 dias. Entretanto, camundongos $\mathrm{CCR}^{-/-}$tiveram uma elevada carga parasitária, tanto no intestino delgado, quanto no fígado, associado ao elevado índice de mortalidade, onde houve letalidade de $100 \%$ dos animais até o $16^{\circ}$ dia após infecção oral. Diferentemente, camundongos deficientes em CCR5 são capazes de controlar a infecção por M. tuberculosis (ALGOOD; FLYNN, 2004), Listeria monocytogenes (ZHONG; KUZIEL et al., 2004) e ainda diminuir o desenvolvimento de malária cerebral, quando animais foram infectados com Plasmodium berghei ANKA (PbA) (BELNOUE et al., 2003). Por outro lado, corroborando os resultados de parasitismo e mortalidade, trabalhos anteriores demonstraram que animais $\mathrm{CCR}^{-/-}$são mais susceptíveis à infecção com T. gondii, cepa ME-49, apresentando uma maior carga parasitária evidenciada pela formação de cistos cerebrais (ALIBERTI; REIS E SOUSA et al., 2000) ou taquizoítas nos demais tecidos (cepa 76K) (KHAN; THOMAS et al., 2006) quando comparados a animais WT.

Associado aos dados de elevado parasitismo nos animais $\mathrm{CCR}^{-1-}$, foram observados também sérias lesões teciduais, em combinação com a formação de infiltrados inflamatórios intensos. Enquanto camundongos WT apresentaram moderado infiltrado inflamatório no íleo, animais $\mathrm{CCR}^{-/-}$apresentaram um intenso infiltrado no $8^{\circ}$ dia após infecção, predominantemente no jejuno e no íleo, com completa desorganização das vilosidades e focos de necrose. Apesar de o infiltrado inflamatório hepático ser semelhante em ambos os animais estudados, nos camundongos deficientes em CCR5 houve uma extensiva vacuolização dos 
hepatócitos, sugestiva de acúmulo de lipídeos.

O diferente infiltrado inflamatório observado no íleo dos animais durante a infecção sugere uma possível deficiência na migração celular dependente da sinalização por CCR5. Ao caracterizar o infiltrado celular na LP foi observada uma elevada freqüência de células TCD4 ${ }^{+}$ entre os linfócitos do intestino delgado e uma diminuída frequência de células NK e NKT nos animais $\mathrm{CCR}^{-/-}$, em comparação com os animais controle C57BL/6. Associado a este achado, não houve diferença na população de células TCD8 ${ }^{+}$entre os animais estudados. No entanto, um estudo mostrou que CCR5 é um importante componente na migração de células TCD8 ${ }^{+}$ intraepiteliais (LUANGSAY; KASPER et al., 2003).

Sabe-se que células $\mathrm{T} C D 4^{+}$produtoras de IFN- $\gamma$ são as principais células mediadoras da resposta inflamatória em infecções por T. gondii (LIESENFELD; KOSEK et al., 1996). Nossos resultados demonstram uma maior freqüência de células T CD4 $4^{+} \mathrm{CD} 25^{-}$nos animais $\mathrm{CCR}^{-/-}$na subpopulação de linfócitos, porém, foi observada uma reduzida concentração de IL-12p40 e IFN- $\gamma$ no íleo de animais $\mathrm{CCR}^{-/-}$quando comparados aos animais WT. Essa diminuída produção de citocinas que induzem efeito microbicida, como IL-12 e IFN- $\gamma$, podem estar relacionados ao descontrole da resposta imune inicial no qual há um elevado parasitismo observado no íleo e no fígado. Uma possível interpretação dos resultados de menor concentração de IL-12 é que CCR5 tem uma importante função na indução da síntese desta citocina após estímulo com antígeno solúvel (STAg) derivado de T. gondii. Esta observação é suportada por meio da observação de que animais $\mathrm{CCR}^{-/-}$possuem uma produção reduzida de IL-12 durante a infecção aguda por este parasito (ALIBERTI; REIS E SOUSA et al., 2000).

Como alguns trabalhos já descreveram o envolvimento de CCR5 no recrutamento celular para o intestino, bem como a participação de tais células na sobrevivência de animais experimentais, optamos por determinar de forma mais apurada como que ocorre a lesão hepática observada na análise histopatológica para entender melhor a importância de CCR5 em infecções por T. gondii. Após infectar as células intestinais, o parasito se dissemina rapidamente por meio de vasos linfáticos para os linfonodos, pelo sangue ao fígado e do fígado aos pulmões e a outros órgãos. Como mencionado anteriormente, um descontrole inicial do parasitismo pode ter levado a uma maior disseminação de T. gondii para o fígado, e tal fato pode estar induzindo à lesão observada.

Ao dissecar os animais, foi observado que o fígado possuía uma coloração pálida, associado ao elevado peso desse órgão nos animais $\mathrm{CCR}^{-/-}$em comparação com animais C57BL/6. A análise microscópica com corante específico revelou elevado acúmulo de ácidos 
graxos no fígado, possivelmente relacionado com elevada concentração de triglicérides e transaminases no soro. Esses dados sugerem uma possível alteração metabólica, decorrente da ausência de CCR5 em combinação com a resposta inflamatória induzida pela infecção.

Alguns estudos têm associado uma possível relação do receptor CCR5 na progressão de doenças do fígado (MURAI et al., 1999; SHIELDS et al., 1999; WOITAS et al., 2002). Independente do recrutamento celular, a ausência do receptor de quimiocina CCR5 leva a um quadro conhecido como falha fulminante do fígado (FLF, do inglês "fulminat liver failure"), quando Concanavalina A (Con A) é administrado em animais experimentais. Esta patologia se dá como resultado da ativação de células NKT CD1d restritas ativadas, residentes no órgão, com produção aumentada de IL-4 e IFN- $\gamma$. (AJUEBOR et al., 2005). Contudo, verificamos que o fígado de animais $\mathrm{CCR}^{-/-}$infectados com $T$. gondii apresentou uma menor concentração de IFN- $\gamma$ e IL-12p40 quando comparados aos animais controle. A ausência de CCR5 pode levar também a ocorrência de hepatite, de forma dependente da produção de TNF- $\alpha$ (MORENO et al., 2005). Em nossos estudos foi observado que a concentração de TGF- $\beta$ foi menor no fígado dos animais $\mathrm{CCR} 5^{-/-}$, porém não houve diferença significativa na concentração de TNF- $\alpha$ nos animais infectados. O desequilíbrio no perfil de citocinas e quimiocinas encontradas no fígado está diretamente relacionado a alterações na migração celular, podendo levar ao processo inflamatório observado.

De forma dependente da migração celular, foi demonstrado que em animais CCR5 ${ }^{-1-}$ infectados com a cepa $76 \mathrm{~K}$ de $T$. gondii, há um alto número de células $\mathrm{NK} 1.1^{+} \mathrm{CD}^{+}$no sangue e no linfonodo mesentérico e em baixos números no baço e no fígado. Esses resultados sugerem que, mesmo na ausência de CCR5, os camundongos conseguem gerar e mobilizar uma resposta de células NKT, porém foram incapazes de recrutar essas células para o sítio de infecção (KHAN; THOMAS et al., 2006). Aumentada expressão hepática de ligantes de CCR5 (CCL5, CCL4 e CCL3) são observadas em biópsias de pacientes com FLF (LEIFELD et al., 2003) e a população de células residentes no fígado é compostas de linfócitos $\mathrm{T} \mathrm{CD}^{+}$e $\mathrm{CD}^{+}$, bem como células NK e NKT, que são componentes chave da imunidade inata e estão em grande quantidade neste órgão (CRISPE, 2003; EXLEY; KOZIEL, 2004). Dessa forma, a ocorrência de toxicidade hepática associada à ausência de CCR5 ainda parece depender de vários fatores e do modelo adotado.

Além dos estudos envolvendo migração celular, muitos trabalhos têm sugerido o uso de perfil de expressão de genes para identificar o mecanismo de toxicidade e classificar ou predizer a toxicidade. Um trabalho investigou uma série de genes no fígado envolvidos na toxicidade hepática causada por um antagonista seletivo de CCR5 (MrkA), potencial 
terapêutico em infecções por HIV. MrkA foi similar a inibidores da $\beta$-oxidação (como o valproato) e agonista de PPAR $\alpha$ (como fenolfibrato e gemfibrozil), indicando que o bloqueio de CCR5 pode estar relacionado com a inibição mitocondrial, causando a lesão tecidual no fígado, caracterizada pela esteatose (CORNWELL; ULRICH, 2007). Nossos dados de expressão gênica no tecido hepático demonstraram que, no $8^{\circ}$ dia após infecção com $T$. gondii, houve diminuída expressão de transcritos para CCL3, CCL4, IL-12p40 e iNOS nos animais $\mathrm{CCR}^{-/-}$, quando comparados aos animais controle $\mathrm{CCR}^{+}$. Além do mais, houve também uma diminuída expressão de Foxp3 e PPAR $\alpha$, fatores de transcrição relacionados à modulação da resposta imunológica. Esses dados, em conjunto com o extenso quadro de vacuolização hepática e acúmulo de lipídeos no fígado, sugerem que esse mecanismo pode estar ocorrendo por bloqueio ou falta de ativação de algumas vias metabólicas envolvendo peroxissomos ou mitocôndria, responsáveis pela $\beta$-oxidação de lipídeos ou via neogênese de lipídeos.

PPARa é conhecido por regular o catabolismo de ácidos graxos e aumentar a transcrição de genes envolvidos no transporte intracelular de ácidos graxos para peroxissomos e mitocôndria para a $\beta$-oxidação (DESVERGNE; WAHLI, 1999). Receptores PPAR (do inglês "Peroxissome Proliferator-activated Receptors") são fatores de transcrição ativados por ligante, pertencentes à superfamília de receptores nucleares de hormônio que inclui esteróides, receptor para vitamina $\mathrm{D}$, ácido retinóico (RA, do inglês "retinoic acid") e receptores de hormônio da tireóide (LAUDET et al., 1992; DESVERGNE; WAHLI, 1999). PPAR $\alpha$ é alvo de uma classe de drogas agonistas conhecidas como fibratos, tais como gemfibrozil e fenolfibrato. Estes fármacos são normalmente utilizados clinicamente para o tratamento de hipertrigliceridemia e são seguros e bem tolerados pelos pacientes (ISSEMANN; GREEN, 1990; ISSEMANN et al., 1993; FORMAN; CHEN; EVANS, 1997; LEHMANN et al., 1997).

Ao tratar os animais infectados com T. gondii com agonista de PPAR $\alpha$, gemfibrozil, foi observado que camundongos $\mathrm{CCR}^{-/-}$apresentaram melhora no quadro de vacuolização hepática, com diminuição na concentração sérica de triglicérides. Esses resultados sugerem que receptores PPAR podem estar relacionados ao mecanismo de indução de esteatose e lesão hepática em animais deficientes de CCR5 em nosso modelo de infecção. De forma interessante, no trabalho onde foram avaliados o perfil gênico envolvido na toxicidade hepática, foi mostrado que a via mais afetada, potencial mecanismo pelo qual a inibição

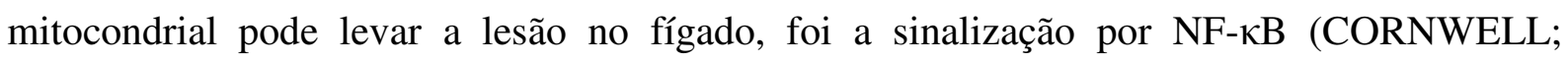
ULRICH, 2007). Dessa forma, fica claro que o efeito primário da ausência de CCR5 é a inibição da $\beta$-oxidação mitocondrial e que no decorrer da infecção por $T$. gondii leva a lesão 
hepática como evidenciado pela esteatose. Tal evento pode estar relacionado também com a ativação da imunidade inata dirigida em parte pela esteatose com subsequente ativação de $\mathrm{NF}-\kappa \mathrm{B}$.

Nossos estudos demonstraram que a ausência de CCR5, após infecção oral por $T$. gondii, leva a um elevado parasitismo nos órgãos periféricos associado a uma alta suscetibilidade, sugerindo que a deficiência desse receptor prejudica um adequado recrutamento e ativação celular e, consequentemente, o controle do parasito. Associado a esses dados foi demonstrado também que a ausência de CCR5 mediante infecção com $T$. gondii causa uma disfunção metabólica elevada no fígado, com acúmulo de lipídeos e alterações na resposta imunológica local. Assim, nós propomos que o CCR5 é essencial para controlar a migração de populações celulares envolvidas no controle do parasito e ativar mediadores microbicidas para o controle da proliferação deste e controlar também a resposta ao metabolismo hepático mediante infecção. 
6. conclusão 


\section{CONCLUSÃO}

Como conclusão, o receptor CCR5 está envolvido no recrutamento de linfócitos $\mathrm{TCD}^{+}{ }^{+}$e células NK para o intestino de animais infectados com T. gondii. Além disso, CCR5 é essencial para ativar mediadores microbicidas e de homeostase no fígado durante a fase aguda de infecção, prevenindo o dano hepático devido ao elevado grau de inflamação causado por este parasito em animais suscetíveis. Receptores PPAR $\alpha$ podem estar envolvidos em um funcionamento hepático regular durante a infecção. 
7 - REFERENNCIAS
BIBLIOGRAFICAS 


\section{REFERÊNCIAS BIBLIOGRÁFICAS}

ADAMS, L. B., HIBBS, J. B., JR., TAINTOR, R. R., KRAHENBUHL, J. L. Microbiostatic effect of murine-activated macrophages for Toxoplasma gondii. Role for synthesis of inorganic nitrogen oxides from L-arginine. J Immunol. v. 144, p. 2725-9, 1990.

AHUJA, S. S., PALIOGIANNI, F., YAMADA, H., BALOW, J. E., BOUMPAS, D. T. Effect of transforming growth factor-beta on early and late activation events in human $\mathrm{T}$ cells. $\mathbf{J}$ Immunol. v. 150, p. 3109-18, 1993.

AJUEBOR, M. N., ASPINALL, A. I., ZHOU, F., LE, T., YANG, Y., URBANSKI, S. J., SIDOBRE, S., KRONENBERG, M., HOGABOAM, C. M., SWAIN, M. G. Lack of chemokine receptor CCR5 promotes murine fulminant liver failure by preventing the apoptosis of activated CD1d-restricted NKT cells. J Immunol. v. 174, p. 8027-37, 2005.

ALGOOD, H. M., FLYNN, J. L. CCR5-deficient mice control Mycobacterium tuberculosis infection despite increased pulmonary lymphocytic infiltration. J Immunol. v. 173, p. 328796, 2004.

ALIBERTI, J. Host persistence: exploitation of anti-inflammatory pathways by Toxoplasma gondii. Nat Rev Immunol. v. 5, p. 162-70, 2005.

ALIBERTI, J., REIS E SOUSA, C., SCHITO, M., HIENY, S., WELLS, T., HUFFNAGLE, G. B., SHER, A. CCR5 provides a signal for microbial induced production of IL-12 by CD8 alpha+ dendritic cells. Nat Immunol. v. 1, p. 83-7, 2000.

ALIBERTI, J., VALENZUELA, J. G., CARRUTHERS, V. B., HIENY, S., ANDERSEN, J., CHAREST, H., REIS E SOUSA, C., FAIRLAMB, A., RIBEIRO, J. M., SHER, A. Molecular mimicry of a CCR5 binding-domain in the microbial activation of dendritic cells. Nat Immunol. v. 4, p. 485-90, 2003.

APPAY, V., ROWLAND-JONES, S. L. RANTES: a versatile and controversial chemokine. Trends Immunol. v. 22, p. 83-7, 2001.

BAGAEVA, L. V., WILLIAMS, L. P., SEGAL, B. M. IL-12 dependent/IFN gamma independent expression of CCR5 by myelin-reactive $\mathrm{T}$ cells correlates with encephalitogenicity. J Neuroimmunol. v. 137, p. 109-16, 2003.

BELNOUE, E., KAYIBANDA, M., DESCHEMIN, J. C., VIGUIER, M., MACK, M., KUZIEL, W. A., RENIA, L. CCR5 deficiency decreases susceptibility to experimental cerebral malaria. Blood. v. 101, p. 4253-9, 2003.

BENEVIDES, L., MILANEZI, C. M., YAMAUCHI, L. M., BENJAMIM, C. F., SILVA, J. S., SILVA, N. M. CCR2 receptor is essential to activate microbicidal mechanisms to control Toxoplasma gondii infection in the central nervous system. Am J Pathol. v. 173, p. 741-51, 2008.

BLISS, S. K., ZHANG, Y., DENKERS, E. Y. Murine neutrophil stimulation by Toxoplasma gondii antigen drives high level production of IFN-gamma-independent IL-12. J Immunol. v. 163, p. 2081-8, 1999. 
BOURGUIN, I., MOSER, M., BUZONI-GATEL, D., TIELEMANS, F., BOUT, D., URBAIN, J., LEO, O. Murine dendritic cells pulsed in vitro with Toxoplasma gondii antigens induce protective immunity in vivo. Infect Immun. v. 66, p. 4867-74, 1998.

BUZONI-GATEL, D., DEBBABI, H., MENNECHET, F. J., MARTIN, V., LEPAGE, A. C., SCHWARTZMAN, J. D., KASPER, L. H. Murine ileitis after intracellular parasite infection is controlled by TGF-beta-producing intraepithelial lymphocytes. Gastroenterology. v. 120, p. $914-24,2001$.

BUZONI-GATEL, D., SCHULTHESS, J., MENARD, L. C., KASPER, L. H. Mucosal defences against orally acquired protozoan parasites, emphasis on Toxoplasma gondii infections. Cell Microbiol. v. 8, p. 535-44, 2006.

COLANTONIO, L., IELLEM, A., SINIGAGLIA, F., D'AMBROSIO, D. Skin-homing CLA+ $\mathrm{T}$ cells and regulatory $\mathrm{CD} 25+\mathrm{T}$ cells represent major subsets of human peripheral blood memory T cells migrating in response to CCL1/I-309. Eur J Immunol. v. 32, p. 3506-14, 2002.

COPPIN, A., DZIERSZINSKI, F., LEGRAND, S., MORTUAIRE, M., FERGUSON, D., TOMAVO, S. Developmentally regulated biosynthesis of carbohydrate and storage polysaccharide during differentiation and tissue cyst formation in Toxoplasma gondii. Biochimie. v. 85, p. 353-61, 2003.

CORNWELL, P. D., ULRICH, R. G. Investigating the mechanistic basis for hepatic toxicity induced by an experimental chemokine receptor 5 (CCR5) antagonist using a compendium of gene expression profiles. Toxicol Pathol. v. 35, p. 576-88, 2007.

CRISPE, I. N. Hepatic T cells and liver tolerance. Nat Rev Immunol. v. 3, p. 51-62, 2003.

DENKERS, E. Y. T lymphocyte-dependent effector mechanisms of immunity to Toxoplasma gondii. Microbes Infect. v. 1, p. 699-708, 1999.

DENKERS, E. Y., GAZZINELLI, R. T. Regulation and function of T-cell-mediated immunity during Toxoplasma gondii infection. Clin Microbiol Rev. v. 11, p. 569-88, 1998.

DESVERGNE, B., WAHLI, W. Peroxisome proliferator-activated receptors: nuclear control of metabolism. Endocr Rev. v. 20, p. 649-88, 1999.

DUBEY, J. P., LINDSAY, D. S., SPEER, C. A. Structures of Toxoplasma gondii tachyzoites, bradyzoites, and sporozoites and biology and development of tissue cysts. Clin Microbiol Rev. v. 11, p. 267-99, 1998.

EXLEY, M. A., KOZIEL, M. J. To be or not to be NKT: natural killer T cells in the liver. Hepatology. v. 40, p. 1033-40, 2004.

FORMAN, B. M., CHEN, J., EVANS, R. M. Hypolipidemic drugs, polyunsaturated fatty acids, and eicosanoids are ligands for peroxisome proliferator-activated receptors alpha and delta. Proc Natl Acad Sci U S A. v. 94, p. 4312-7, 1997. 
FRENKEL, J. K. Pathophysiology of toxoplasmosis. Parasitol Today. v. 4, p. 273-8, 1988.

GAZZINELLI, R. T., HAKIM, F. T., HIENY, S., SHEARER, G. M., SHER, A. Synergistic role of CD4+ and CD8+ T lymphocytes in IFN-gamma production and protective immunity induced by an attenuated Toxoplasma gondii vaccine. J Immunol. v. 146, p. 286-92, 1991.

GAZZINELLI, R. T., WYSOCKA, M., HAYASHI, S., DENKERS, E. Y., HIENY, S., CASPAR, P., TRINCHIERI, G., SHER, A. Parasite-induced IL-12 stimulates early IFNgamma synthesis and resistance during acute infection with Toxoplasma gondii. J Immunol. v. 153 , p. $2533-43,1994$.

GUY-GRAND, D., GRISCELLI, C., VASSALLI, P. The mouse gut T lymphocyte, a novel type of T cell. Nature, origin, and traffic in mice in normal and graft-versus-host conditions. $\mathbf{J}$ Exp Med. v. 148, p. 1661-77, 1978.

HUNTER, C. A., REMINGTON, J. S. Immunopathogenesis of toxoplasmic encephalitis. J Infect Dis. v. 170, p. 1057-67, 1994.

IELLEM, A., MARIANI, M., LANG, R., RECALDE, H., PANINA-BORDIGNON, P., SINIGAGLIA, F., D'AMBROSIO, D. Unique chemotactic response profile and specific expression of chemokine receptors CCR4 and CCR8 by CD4(+)CD25(+) regulatory T cells. J Exp Med. v. 194, p. 847-53, 2001.

ISSEMANN, I., GREEN, S. Activation of a member of the steroid hormone receptor superfamily by peroxisome proliferators. Nature. v. 347, p. 645-50, 1990.

ISSEMANN, I., PRINCE, R. A., TUGWOOD, J. D., GREEN, S. The peroxisome proliferator-activated receptor:retinoid $\mathrm{X}$ receptor heterodimer is activated by fatty acids and fibrate hypolipidaemic drugs. J Mol Endocrinol. v. 11, p. 37-47, 1993.

JOHNSON, A. M. Strain-dependent, route of challenge-dependent, murine susceptibility to toxoplasmosis. Z Parasitenkd. v. 70, p. 303-9, 1984.

JONES, J. L., KRUSZON-MORAN, D., SANDERS-LEWIS, K., WILSON, M. Toxoplasma gondii infection in the United States, 1999 2004, decline from the prior decade. Am J Trop Med Hyg. v. 77, p. 405-10, 2007.

KASPER, L., COURRET, N., DARCHE, S., LUANGSAY, S., MENNECHET, F., MINNS, L., RACHINEL, N., RONET, C., BUZONI-GATEL, D. Toxoplasma gondii and mucosal immunity. Int J Parasitol. v. 34, p. 401-9, 2004.

KHAN, I. A., THOMAS, S. Y., MORETTO, M. M., LEE, F. S., ISLAM, S. A., COMBE, C., SCHWARTZMAN, J. D., LUSTER, A. D. CCR5 is essential for NK cell trafficking and host survival following Toxoplasma gondii infection. PLoS Pathog. v. 2, p. e49, 2006.

KRICK, J. A., REMINGTON, J. S. Toxoplasmosis in the adult--an overview. N Engl J Med. v. 298, p. 550-3, 1978.

KUNKEL, E. J., CAMPBELL, J. J., HARALDSEN, G., PAN, J., BOISVERT, J., ROBERTS, A. I., EBERT, E. C., VIERRA, M. A., GOODMAN, S. B., GENOVESE, M. C., 
WARDLAW, A. J., GREENBERG, H. B., PARKER, C. M., BUTCHER, E. C., ANDREW, D. P., AGACE, W. W. Lymphocyte CC chemokine receptor 9 and epithelial thymusexpressed chemokine (TECK) expression distinguish the small intestinal immune compartment: Epithelial expression of tissue-specific chemokines as an organizing principle in regional immunity. J Exp Med. v. 192, p. 761-8, 2000.

LANGERMANS, J. A., VAN DER HULST, M. E., NIBBERING, P. H., HIEMSTRA, P. S., FRANSEN, L., VAN FURTH, R. IFN-gamma-induced L-arginine-dependent toxoplasmastatic activity in murine peritoneal macrophages is mediated by endogenous tumor necrosis factor-alpha. J Immunol. v. 148, p. 568-74, 1992.

LAUDET, V., HANNI, C., COLL, J., CATZEFLIS, F., STEHELIN, D. Evolution of the nuclear receptor gene superfamily. EMBO J. v. 11, p. 1003-13, 1992.

LEHMANN, J. M., LENHARD, J. M., OLIVER, B. B., RINGOLD, G. M., KLIEWER, S. A. Peroxisome proliferator-activated receptors alpha and gamma are activated by indomethacin and other non-steroidal anti-inflammatory drugs. J Biol Chem. v. 272, p. 3406-10, 1997.

LEIFELD, L., DUMOULIN, F. L., PURR, I., JANBERG, K., TRAUTWEIN, C., WOLFF, M., MANNS, M. P., SAUERBRUCH, T., SPENGLER, U. Early up-regulation of chemokine expression in fulminant hepatic failure. J Pathol. v. 199, p. 335-44, 2003.

LIESENFELD, O. Oral infection of C57BL/6 mice with Toxoplasma gondii: a new model of inflammatory bowel disease? J Infect Dis. v. 185 Suppl 1, p. S96-101, 2002.

LIESENFELD, O., KANG, H., PARK, D., NGUYEN, T. A., PARKHE, C. V., WATANABE, H., ABO, T., SHER, A., REMINGTON, J. S., SUZUKI, Y. TNF-alpha, nitric oxide and IFN-gamma are all critical for development of necrosis in the small intestine and early mortality in genetically susceptible mice infected perorally with Toxoplasma gondii. Parasite Immunol. v. 21, p. 365-76, 1999.

LIESENFELD, O., KOSEK, J., REMINGTON, J. S., SUZUKI, Y. Association of CD4+ T cell-dependent, interferon-gamma-mediated necrosis of the small intestine with genetic susceptibility of mice to peroral infection with Toxoplasma gondii. J Exp Med. v. 184, p. 597-607, 1996.

LIM, H. W., HILLSAMER, P., KIM, C. H. Regulatory T cells can migrate to follicles upon T cell activation and suppress $\mathrm{GC}-\mathrm{Th}$ cells and $\mathrm{GC}-\mathrm{Th}$ cell-driven $\mathrm{B}$ cell responses. J Clin Invest. v. 114, p. 1640-9, 2004.

LOETSCHER, P., UGUCCIONI, M., BORDOLI, L., BAGGIOLINI, M., MOSER, B., CHIZZOLINI, C., DAYER, J. M. CCR5 is characteristic of Th1 lymphocytes. Nature. v. 391, p. 344-5, 1998.

LUANGSAY, S., KASPER, L. H., RACHINEL, N., MINNS, L. A., MENNECHET, F. J., VANDEWALLE, A., BUZONI-GATEL, D. CCR5 mediates specific migration of Toxoplasma gondii-primed CD8 lymphocytes to inflammatory intestinal epithelial cells. Gastroenterology. v. 125, p. 491-500, 2003. 
MENNECHET, F. J., KASPER, L. H., RACHINEL, N., LI, W., VANDEWALLE, A., BUZONI-GATEL, D. Lamina propria CD4+ T lymphocytes synergize with murine intestinal epithelial cells to enhance proinflammatory response against an intracellular pathogen. $\mathbf{J}$ Immunol. v. 168, p. 2988-96, 2002.

MENNECHET, F. J., KASPER, L. H., RACHINEL, N., MINNS, L. A., LUANGSAY, S., VANDEWALLE, A., BUZONI-GATEL, D. Intestinal intraepithelial lymphocytes prevent pathogen-driven inflammation and regulate the Smad/T-bet pathway of lamina propria CD4+ T cells. Eur J Immunol. v. 34, p. 1059-67, 2004.

MONTOYA, J. G., LIESENFELD, O. Toxoplasmosis. Lancet. v. 363, p. 1965-76, 2004.

MOREIRA, A. P., CAVASSANI, K. A., MASSAFERA TRISTAO, F. S., CAMPANELLI, A. P., MARTINEZ, R., ROSSI, M. A., SILVA, J. S. CCR5-dependent regulatory T cell migration mediates fungal survival and severe immunosuppression. J Immunol. v. 180, p. 3049-56, 2008.

MORENO, C., GUSTOT, T., NICAISE, C., QUERTINMONT, E., NAGY, N., PARMENTIER, M., LE MOINE, O., DEVIERE, J., LOUIS, H. CCR5 deficiency exacerbates T-cell-mediated hepatitis in mice. Hepatology. v. 42, p. 854-62, 2005.

MOSER, B., LOETSCHER, P. Lymphocyte traffic control by chemokines. Nat Immunol. v. 2, p. 123-8, 2001.

MOTSINGER, A., HAAS, D. W., STANIC, A. K., VAN KAER, L., JOYCE, S., UNUTMAZ, D. CD1d-restricted human natural killer T cells are highly susceptible to human immunodeficiency virus 1 infection. J Exp Med. v. 195, p. 869-79, 2002.

MURAI, M., YONEYAMA, H., HARADA, A., YI, Z., VESTERGAARD, C., GUO, B., SUZUKI, K., ASAKURA, H., MATSUSHIMA, K. Active participation of CCR5(+)CD8(+) $\mathrm{T}$ lymphocytes in the pathogenesis of liver injury in graft-versus-host disease. J Clin Invest. v. 104, p. 49-57, 1999.

NG-CASHIN, J., KUHNS, J. J., BURKETT, S. E., POWDERLY, J. D., CRAVEN, R. R., VAN DEVENTER, H. W., KIRBY, S. L., SERODY, J. S. Host absence of CCR5 potentiates dendritic cell vaccination. J Immunol. v. 170, p. 4201-8, 2003.

NICHOLS, B. A., O'CONNOR, G. R. Penetration of mouse peritoneal macrophages by the protozoon Toxoplasma gondii. New evidence for active invasion and phagocytosis. Lab Invest. v. 44, p. 324-35, 1981.

OLDENHOVE, G., BOULADOUX, N., WOHLFERT, E. A., HALL, J. A., CHOU, D., DOS SANTOS, L., O'BRIEN, S., BLANK, R., LAMB, E., NATARAJAN, S., KASTENMAYER, R., HUNTER, C., GRIGG, M. E., BELKAID, Y. Decrease of Foxp3+ Treg cell number and acquisition of effector cell phenotype during lethal infection. Immunity. v. 31, p. 772-86, 2009.

SALLUSTO, F., LENIG, D., FORSTER, R., LIPP, M., LANZAVECCHIA, A. Two subsets of memory $\mathrm{T}$ lymphocytes with distinct homing potentials and effector functions. Nature. $\mathrm{v}$. 401, p. 708-12, 1999. 
SCHALL, T. J. Biology of the RANTES/SIS cytokine family. Cytokine. v. 3, p. 165-83, 1991.

SHIELDS, P. L., MORLAND, C. M., SALMON, M., QIN, S., HUBSCHER, S. G., ADAMS, D. H. Chemokine and chemokine receptor interactions provide a mechanism for selective $\mathrm{T}$ cell recruitment to specific liver compartments within hepatitis C-infected liver. J Immunol. v. 163 , p. $6236-43,1999$.

SILVA, N. M., VIEIRA, J. C., CARNEIRO, C. M., TAFURI, W. L. Toxoplasma gondii: the role of IFN-gamma, TNFRp55 and iNOS in inflammatory changes during infection. Exp Parasitol. v. 123, p. 65-72, 2009.

SUZUKI, Y., SHER, A., YAP, G., PARK, D., NEYER, L. E., LIESENFELD, O., FORT, M., KANG, H., GUFWOLI, E. IL-10 is required for prevention of necrosis in the small intestine and mortality in both genetically resistant BALB/c and susceptible C57BL/6 mice following peroral infection with Toxoplasma gondii. J Immunol. v. 164, p. 5375-82, 2000.

TENTER, A. M., HECKEROTH, A. R., WEISS, L. M. Toxoplasma gondii: from animals to humans. Int J Parasitol. v. 30, p. 1217-58, 2000.

THOMAS, S. Y., HOU, R., BOYSON, J. E., MEANS, T. K., HESS, C., OLSON, D. P., STROMINGER, J. L., BRENNER, M. B., GUMPERZ, J. E., WILSON, S. B., LUSTER, A. D. CD1d-restricted NKT cells express a chemokine receptor profile indicative of Th1-type inflammatory homing cells. J Immunol. v. 171, p. 2571-80, 2003.

VOSSENKAMPER, A., STRUCK, D., ALVARADO-ESQUIVEL, C., WENT, T., TAKEDA, K., AKIRA, S., PFEFFER, K., ALBER, G., LOCHNER, M., FORSTER, I., LIESENFELD, O. Both IL-12 and IL-18 contribute to small intestinal Th1-type immunopathology following oral infection with Toxoplasma gondii, but IL-12 is dominant over IL-18 in parasite control. Eur J Immunol. v. 34, p. 3197-207, 2004.

WANG, C. R., LIU, M. F. Regulation of CCR5 expression and MIP-1alpha production in CD4+ T cells from patients with rheumatoid arthritis. Clin Exp Immunol. v. 132, p. 371-8, 2003.

WOITAS, R. P., AHLENSTIEL, G., IWAN, A., ROCKSTROH, J. K., BRACKMANN, H. H., KUPFER, B., MATZ, B., OFFERGELD, R., SAUERBRUCH, T., SPENGLER, U. Frequency of the HIV-protective CC chemokine receptor 5-Delta32/Delta32 genotype is increased in hepatitis C. Gastroenterology. v. 122, p. 1721-8, 2002.

YAP, G. S., SHER, A. Cell-mediated immunity to Toxoplasma gondii: initiation, regulation and effector function. Immunobiology. v. 201, p. 240-7, 1999.

YURCHENKO, E., TRITT, M., HAY, V., SHEVACH, E. M., BELKAID, Y., PICCIRILLO, C. A. CCR5-dependent homing of naturally occurring CD4+ regulatory $\mathrm{T}$ cells to sites of Leishmania major infection favors pathogen persistence. J Exp Med. v. 203, p. 2451-60, 2006. 
ZABEL, B. A., AGACE, W. W., CAMPBELl, J. J., HEATH, H. M., PARENT, D., ROBERTS, A. I., EBERT, E. C., KASSAM, N., QIN, S., ZOVKO, M., LAROSA, G. J., YANG, L. L., SOLER, D., BUTCHER, E. C., PONATH, P. D., PARKER, C. M., ANDREW, D. P. Human G protein-coupled receptor GPR-9-6/CC chemokine receptor 9 is selectively expressed on intestinal homing $\mathrm{T}$ lymphocytes, mucosal lymphocytes, and thymocytes and is required for thymus-expressed chemokine-mediated chemotaxis. J Exp Med. v. 190, p. 1241$56,1999$.

ZHONG, M. X., KUZIEL, W. A., PAMER, E. G., SERBINA, N. V. Chemokine receptor 5 is dispensable for innate and adaptive immune responses to Listeria monocytogenes infection. Infect Immun. v. 72, p. 1057-64, 2004. 
8. ANEXOS 


\section{ANEXOS}

8.1. Parecer da comissão de ética em experimentação animal

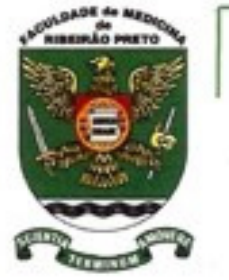

\section{UNIVERSIDADE DE SÄO PAULO \\ FACULDADE DE MEDICINA DE RIBEIRÄO PRETO}

— Comissão de Ética em Experimentação Animal —

\section{CE R TIFICADO}

Certificamos que o Protocolo para Uso de Animais em Experimentação $\mathbf{n}^{\circ} \mathbf{2 0 0 / 2 0 0 9}$, sobre o projeto intitulado "Papel de CCR5 na infecção oral por Toxoplasma gondii", sob a responsabilidade do Professor Doutor João Santana da Silva está de acordo com os Princípios Éticos na Experimentação Animal adotado pelo Colégio Brasileiro de Experimentação Animal (COBEA) e foi $\boldsymbol{A P R O V A D O}$ em reunião de 22 de fevereiro de 2010.

(We certify that the protocol $n^{\circ} 200 / 2009$, about "The role of CCR5 in the Toxoplasma gondii oral infection", agrees with the ETHICAL PRINCIPLES IN ANIMAL RESEARCH adopted by Brazilian College of Animal Experimentation (COBEA) and was approved "ad referendum" by the College of Medicine of Ribeirão Preto of the University of São Paulo - Ethical Commission of Ethics in Animal Research (CETEA) in 02/22/2010 meeting.

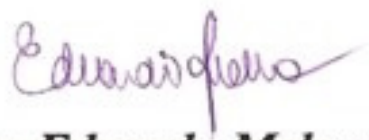

Prof. Dr. Eduardo Melani Rocha Presidente da Comissão de Ética em Experimentação Animal 